Florida International University FIU Digital Commons

3-24-1998

\title{
The other side of the kitchen door: Domestic service in Lima, Peru
}

Elena Sabogal Bee

Florida International University

DOI: $10.25148 /$ etd.FI14050469

Follow this and additional works at: https:// digitalcommons.fiu.edu/etd

Cart of the Sociology Commons

\section{Recommended Citation}

Bee, Elena Sabogal, "The other side of the kitchen door: Domestic service in Lima, Peru" (1998). FIU Electronic Theses and Dissertations. 1465.

https://digitalcommons.fiu.edu/etd/1465

This work is brought to you for free and open access by the University Graduate School at FIU Digital Commons. It has been accepted for inclusion in FIU Electronic Theses and Dissertations by an authorized administrator of FIU Digital Commons. For more information, please contact dcc@fiu.edu. 


\section{FLORIDA INTERNATIONAL UNIVERSITY \\ Miami, Florida}

\section{The Other Side of the Kitchen Door: \\ Domestic Service in Lima, Peru}

A thesis submitted in partial satisfaction of the

requirements for the degree of

MASTER OF ARTS

IN

COMPARATIVE SOCIOLOGY

by

Elena Sabogal Bee 
To: Dean Arthur W. Herriott

College of Arts and Sciences

This thesis, written by Elena Sabogal Bee, and entitled The Other Side of the Kitchen Door: Domestic Service in Lima, Peru, having been approved in respect to style and intellectual content, is referred to you for judgement.

We have read this thesis and recommend that it be approved.

Janet Chernela

James Ito-Adler

Stephen Fjellman, Major Professor

Date of Defense: March 24, 1998

The thesis of Elena Sabogal Bee is approved.

Dean Arthur W. Herriott

College of Arts and Sciences

Dr. Richard L. Campblell

Dean of Graduate Studies

Florida International University, 1998 
๑) COPYRIGHT 1998 by Elena Sabogal Bee

All rights reserved 
I dedicate this thesis to my family:

to Richard, who often helped me elucidate and articulate my thoughts - for his love, strength, and help throughout the years of our life and travels together;

to our children, Andrew and Patrick, for their patience and encouragement, and their understanding of the reasons why I could not be there for them sometimes;

to my professor, Dr. James Ito-Adler, who although not of my "tribe" has an honored place on my kinship chart, for the sharing of his knowledge and time, and his caring about my work. Thank you Doctor, for it was your spark that lit the fire and set me on this path of understanding;

and

to the memory of Alejandro Seminario, my grandfather, who expected me to pursue my education, encouraged me to read, and often reminded me to never stop questioning. 


\section{ACKNOWLEDGMENTS}

I would like to thank my grandmother, Elena, for sharing with me the colorful stories of her travels and adventures which gave me the interest to pursue anthropology; my parents, Elena and Polo, for their love, their encouragement, and their acceptance of the seemingly "crazy" ideas I have pursued throughout my life so far; my sisters Maria Luisa, Delfina, Maricarmen, and my brother Enrique for their love and support, and for the many adventures we shared among ourselves and with the empleadas in our household when we were children. To all, thank you for helping me take care of my children while I was occupied with my fieldwork in Lima.

My childhood friends, Rosa Maria De Armenteras and Maria Luisa Choza, for the good times and love we have shared since kindergarten; Patricia Landa and Virginia Tode, for our adventures together during the years of travels to those far off places that dreams are made of; Alma Cirugeda Suarez, Michelle Lamarre, Cristina Finlay and Clara Galvez, for their friendship, help, and the many laughs we have shared in the office.

Professor Kathleen Martín, for her generous provision of research materials relating to domestic service in Latin America and her advice concerning positionality and reflexivity contained in this thesis. The members of my committee: Professor Janet Chernela, for her support, editing, and encouragement to pursue my work since we first met during my undergraduate years. Her insightful comments were always right on target. Professor James Ito-Adler, my advisor, mentor, editor, and friend throughout my undergraduate and graduate years. His training, faith in my abilities, and selection of topic started it all. My major professor,

Dr. Stephen Fjellman, for his kindness, support, and encouraging comments. He often provided a much needed tranquillity and shelter from the storm.

Finally, I also wish to thank the señoras and empleadas who opened their hearts and minds and provided me the opportunity to pass back and forth through the kitchen door and without whose help I would not have been able to tell the story. 


\title{
ABSTRACT OF THE THESIS
}

\section{THE OTHER SIDE OF THE KITCHEN DOOR: DOMESTIC SERVICE IN LIMA, PERU}

\author{
by
}

\section{Elena Sabogal Bee}

Florida International University, 1998

\author{
Miami, Florida
}

\section{Professor Stephen Fjellman, Major Professor}

Domestic service refers to the work required to complete duties pertaining to the maintenance and functioning of the household, particularly when performed by employed labor. This study provides an ethnographic account of domestic service through an analysis of social behavior and cultural patterns. The participants in the social structure of domestic service are the señora (the lady of the house), her family, and the empleadas (domestic workers) all of whom have specific social identities and roles within the household. The señora/empleada dyad is central to the institution and all other participants are secondary. This study contributes to the growing body of work in anthropology that concentrates on elite sectors of society and explores theoretical issues relating to gender, class, and ethnic differences in Peru. 


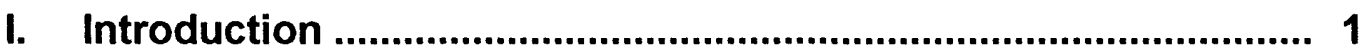

Literature Review .......................................................................... 3

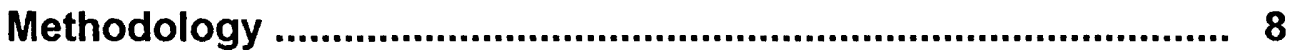

Choosing the Cultural Scene .......................................... 9

Informants .............................................................................. 11

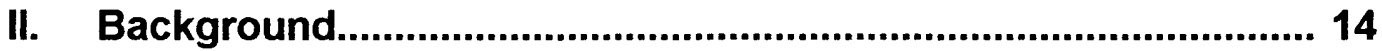

Historical Perspective of Domestic Service in Peru ................... 14

Peruvian Social Structure............................................................ 18

Migration to Lima...................................................................... 22

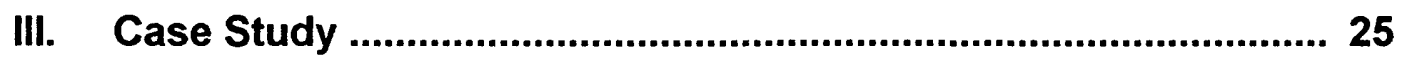

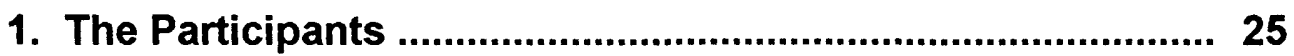

The Empleadas ............................................................. 25

The Señoras ...................................................................... 28

2. Work and Responsibility ................................................ 32

The Señoras' Perspective .............................................. 32

Hiring an Empleada $\quad$.................................................. 34

The Empleadas' Perspective ........................................... 36

3. Social Distance .................................................................... 38

The Empleadas' Perspective ........................................ 38

The Señoras' Perspective ............................................. 40

4. Secondary Participants .......................................................... 44

The Children of the Household ...................................... 44

The Señores of the Household ..................................... 47

5. Conflict and Mutual Distrust ........................................... 50

Household Privacy ........................................................ 50

The Señoras and the Empleadas .................................. 51

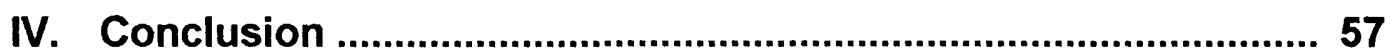

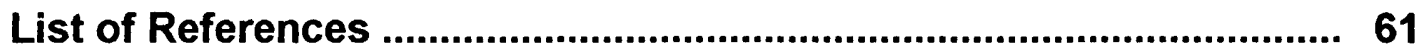




\section{CHAPTER I: INTRODUCTION}

This thesis is a case study of domestic service in Lima, Peru. The term "domestic servicen generally refers to the many and varied types of work required to complete those duties pertaining to the maintenance, functioning, and day-to-day running of the household, particularly when performed by employed labor. In Peru, as in most countries where the institution is found, domestic service is performed by women who belong to the marginal classes of society for families from the favored classes. These women, who have a lower economic and social status than their employers, are paid to do such household chores as cleaning, cooking, washing, ironing, and child care for individuals or a family in the privacy of a household, as well as various external tasks completed outside the home such as shopping, childcare-related activities, and errands.

The research for this thesis focused on a sample of urban upper-middle class women living in the district of San Isidro in Lima and their live-in domestic workers. Following Peruvian usage, I will refer to the upper-middle class women in my sample as señoras, and their live-in domestic workers as empleadas. My goal with this thesis is to provide an ethnographic account of domestic service in this setting through an analysis of the social behavior and cultural patterns that constitute the institution.

Following Spradley and Mann (1975), I differentiate in my analysis between what they term the "social structure" of the institution and the "social networks" that constitute it. They define the social structure as composed of "an organized set of social identities and the expected behavior associated with them" (1975:60). The participants in the social structure of domestic service are the señora (the "Mrs." or "lady of the house"); her husband, the señor; their children; and the empleada(s), all of whom have specific social identities and roles within the household. In order to see how these participants use the social structure and operate within its constraints, however, we must shift focus to the realm of social networks. Social network analysis, according 
to Spradley and Mann, allows a view of the social structure as "it is seen through the eyes of individual members" (1975:63). In fact, the señoras and the empleadas in my sample, not surprisingly, see the institution from very different perspectives. From my anthropological perspective as an outside observer, it is the interaction between them from their disparate standpoints that defines the characteristic features of the institution.

To anticipate some of my conclusions, I found that the working relationship between the señora and empleada is one of physical closeness, but social distance. Both the señora and the empleada have multiple, specific, and complex roles, and their daily interactions are characterized by a tense combination of "team work" and "mutual distrust." It is clear, nevertheless, that the señora/empleada dyad is central to the institution and that all other participants--the children and the husband, for example--are secondary. All of the activities carried out by the empleadas are in the realm of the señora's responsibility in the household.

Inside a household, the señora and the empleada work as a team; in part to craft performances for others, but they never completely trust each other. Erving Goffman uses the term "team" to designate "any set of individuals who co-operate in staging a single routine" (1959:79). He argues that "when members of a team have different formal statuses...the mutual dependence created by membership in the team is likely to cut across structural or social cleavages in the establishment and thus provide a source of cohesion for the establishment" (1959:82). Teammates, according to Goffman, may be bound by familiarity, albeit a familiarity that "may constitute a kind of intimacy without warmth" (1959:83). In Goffman's dramaturgical approach to understanding teams, even if the audience is not physically present, it figures in the way team members present themselves in everyday life. He notes that "a team itself may stage a performance for an audience that is not present in the flesh to witness the show" (1959:82).

The close-yet-distant relationship maintained between señora and empleada reveals a degree of mutual distrust embedded in the daily roles and interactions within the household. The señora depends on the empleada to allow her to maintain a specific and expected standard of presentation, while the empleada depends on the señora for economic survival. They act as a 
team or unit; yet, they do not trust each other. This contradiction establishes a symbiotic relationship of reliance and dependence upon one another.

Thus, by focusing on this vital relationship, this study contributes to the growing body of work in anthropology that concentrates on elite sectors of society and explores theoretical issues relating to gender, class, and ethnic differences in Peru.

\section{LITERATURE REVIEW}

An extensive literature exists describing the perspectives of domestic workers. Muchachas No More, a book edited by Elsa M. Chaney and Mary Garcia Castro (1989), presents the most complete collection of articles written about domestic service in Latin America and the Caribbean. Chaney and Castro claim that the studies presented in their book "will contribute toward making the situation of domestic workers better known and understood" (1989:10). A review of the articles in their collection reveals a number of interesting issues; nevertheless, there remains a lack of focus on the very women who employ domestic workers.

Garcia Castro raises the issue of "whether or not it is possible to eliminate the element of subordination in the empleada/patrona relationship" by providing an economic ideological framework "within which patronas and empleadas relate" (1989:106). According to her, unionized domestic work in Colombia fits within "an ideological framework shared by domestic workers and their employers alike, that conditions and legitimizes the low wages in domestic

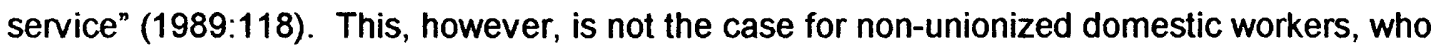
tend to value "good treatment" more than a good salary.

Garcia Castro suggests that domestic workers tend to view their present working conditions positively when compared with previous and often negative experiences in rural areas (1989:118). Leslie Gill, on the other hand, argues on the basis of her work in La Paz, Bolivia, that domestic workers "feel strong emotional attachments to rural kinfolk" (1994:100). She goes on to point out that, although domestic workers "can not always return to the countryside on a regular basis," they do return to the countryside at least once a year, generally coinciding with 
community events. This is done in order to maintain ties to their rural communities, which are crucial to their survival in the city. Domestic workers' feelings about their ties to their communities may become ambivalent or attenuated with time, not because of negative experiences as Garcia Castro suggests, but as a result of their removal from rural life (Gill, 1994:102). Furthermore, Shellee Colen in her study of West Indian women domestics in New York also suggests that "visions of their families and futures" allow domestic workers to cope with and adapt to not only migration, but also domestic work (1989:187).

One important aspect of domestic service brought out in the literature is the asymmetrical relationship established between señora and empleada as a result of structural and historical circumstances. Judith Rollins suggests that "in no other labor arrangement is it typical for both employer and employee to be female, both members of the subordinate gender" (1985:6-7). She further argues that the dynamics of the señora/empleada relationship provide an excellent case of "a relationship of domination in close quarters" (1985:8). Although both are women, there are class and racial constraints, as well as other factors, that limit a more symmetrical or equal relationship between them. June Nash and Helen Safa (1980) argue that in Third World countries, class inequalities take priority over sex inequalities. Mary Romero, however, suggests that asymmetrical relationships in domestic service may be extended to employers and domestic workers in the United States as well, pointing out that in the United States "affluent women are hiring poorer women to work long hours at relatively low wages and with no benefits to replace them in the household" (1992:98). Furthermore, she claims that this inequality between women maintains "through systems of gender, class, and racial domination" a system of exploitation regardless of the fact that both employer and worker are women (1992:98). In her analysis of the mistress/servant relationship in Bolivia, Leslie Gill (1994) demonstrates uncomfortable parallels to the American employer/employee relationship due to the exercise of power; consequently, as she points out, "domestic service is an important arena in which to explore the changing class, gender, and ethnic relations that shape social life" (1994:6). 
In his analysis of racism, Juan Carlos Callirgos (1993) maintains that in Peruvian society there is a clear connection between race and class that defines cultural and socio-economic differences. Historically, the social distance evident in Peruvian society is caused by the elite's incapacity to accept the majority of people as equal and has impeded the formation of a national identity (Matos Mar, 1988; Portocarrero, 1990; Callirgos, 1993). As a result, Callirgos defines racism as "the radical manner of blocking any possibility to establish reciprocal relationships with the other." He goes on to point out that "racism is a way to look at and relate to the other, but at the same time it reveals the way in which one looks at oneself" (1993:21). I agree with Callirgos that institutionalized racism requires upper-middle class women to maintain certain social distance due to historically perceived class differences between themselves and their domestic workers.

Spradley and Mann argue that there is an unavoidable "territorial dimension of existence $^{n}$ which can help understand this situation (1975:101). Due to the fact that space is organized in distinct ways in different societies, they claim that "territoriality" is a universal phenomenon bound with cultural meanings, that relate to the ways "by which space is defined, allocated, and maintained" (1975:101). Since social interaction invariably takes place in specific physical settings, individuals are inclined to assert their positions within this physical space, and through it their social identities become "intertwined with the meaning of space" (1975:147). As a result, there is a "hidden dimension" of space located "largely outside of awareness," which reveals that space conveys symbolic messages (Spradley \& Mann, 1975:102).

Edward Hall argues that in societies in which class systems exist, the handling of space will reflect the class positions of its members (1959:201). Therefore "the formal patterning of space can take on varying degrees of importance and complexity" and houses and towns will reflect the social ranking (1959:202). The traditional physical settings found in upper-middle class Peruvian households clearly indicate the importance given to class differences. Within these households there are two clearly delineated areas in which the members of the household dwell. The empleadas' quarters are separated from the family quarters by the kitchen door, 
beyond which lie the kitchen area, the laundry area, and finally the empleadas' living quarters, which consist of a small bedroom, a shower, and a toilet. Because of the distinct delineation of territory represented by the doorway between the kitchen and the remainder of the house, I chose the title of my work to convey this hidden picture .

Pierre Bourdieu in Distinction maintains that "social identity is defined and asserted through difference" (1984:172). Thus, in order to establish social identity, the social space of everyday life becomes relevant to the analysis of how social distance is upheld or signaled by the upper classes in their daily interactions with the working classes (1984:169). Bourdieu's work focuses on the dialectical relationship between objective structures and subjective phenomena or the relationship "between social structures and mental structures" (1984:471). He uses the concepts of habitus and field to deal with these issues. Habitus refers to the "mental or cognitive structures" through which people deal with the social world and thus designates the "internalized, 'embodied' social structures" (Bourdieu, 1984:468). The habitus, then, both produces and is produced by the social world. The field, on the other hand, refers to a network of relations among the objective positions within it. These relations exist apart from individual consciousness and will, and the occupants of positions may be either agents or institutions constrained by the structure of the field. The dialectical relationship between habitus and field mutually defines one another: Bourdieu notes that:

The dispositions constituting the cultivated habitus are only formed, only function and are only valid in a field, in the relationship with a field. . . which is itself a 'field of possible forces,' a 'dynamic' situation in which forces are only manifested in their relationship with certain dispositions. This is why the same practices may receive opposite meanings and values in different fields, in different configurations, or in opposing sectors of the same field (1984:94).

Consequently, Bourdieu points out the importance of presenting both the dominant and subordinate perspectives of groups in society to obtain "a full account of the objective relations between the groups" (1984:13). Bourdieu argues that to present one perspective would therefore 
offer only one group's "partial truth." It is then within the household where most contradictions are to be found in the asymmetrical relationship between the señora and empleada.

The relationship and interaction between these players in the domestic sphere involves intense personal closeness and propinquity, yet the physical space they cohabit is clearly delineated, bounded, and defined. The contradictory perceptions, values, beliefs, and motives expressed by these women on both sides of the relationship are grounded in their distinct cultural backgrounds and socio-economic situations. As this study demonstrates, they are bound into a single institution based upon what Goffman calls "bonds of reciprocal dependence and reciprocal familiarity" (1959:83). He further suggests that:

a set of individuals who might be dissimilar in important respects, and hence desirous of maintaining social distance from one another, find they are in a relation of enforced familiarity characteristic of teammates engaged in staging a show (1959:84).

Even though an empleada is by definition in a position of subordination to the señora within the household, domestic workers have a unique opportunity to observe their employers backstage within this private realm. This opportunity to view the family au naturel is denied to any other outsider, and as a result this familiarity empowers the domestic worker. This possibility arises as a result of domestic workers' placement in "non-person" roles within the household (Rollins, 1985:210). Although employers often claim that they consider domestic workers part of their families, Rollins's research suggests that they treat domestic workers as "non-persons." This "invisibility" provides domestic workers with the occasion to "observe the contradiction between what employers want to present to the public and what the reality is" (1985:215).

Robert Murphy contends that roles are "cultural only to the extent that they become value-embedded, or institutionalized" (1971:56). According to Murphy, culture "institutionalizes the role system, and it becomes internalized within the personality" (1971:57). Similarly, Spradley and Mann argue that cross-cultural research has shown that "some identities have less value than others, giving rise to different systems of inequality" (1975:10). Thus, individuals holding a subordinate status are more likely to experience less respect and to be regarded as 
objects rather than persons. This suggests, according to Spradley and Mann, that whenever certain individuals are seen as objects rather than persons, other individuals situated in dominant positions will tend to "invade their privacy without hesitation, talk about them in their presence, manipulate their behavior, and keep them in their assigned places" (1975:11). Hence, this shift from person to object indicates how the subordinate group acquires social invisibility and how this invisibility extends to social situations in which "they must remain in the background" $(1975: 10)$. By focusing on this aspect of social invisibility as experienced by domestic workers in the United States, Rollins neglects to examine another aspect that I believe is of profound relevance: the notion of privacy. When employers have had "outsiders" or domestic workers living within their households all of their lives, one needs to question the concept of "privacy" and how this is understood in dialectical terms.

In order to advance a broader understanding of domestic service as a social institution, its constituent roles, and the behavior associated with those roles, this thesis attempts to present a more balanced picture of the social interaction between the two main participants involved. Since the perspective of domestic workers has been documented in great detail in the academic literature, the present contribution provides an analysis of how this institution operates that focuses first on the perspective of the señoras. However, in order to offer a more even handed description of their daily social interaction and relationship, I will alternate between the accounts provided by señoras and empleadas.

\section{METHODOLOGY}

This study is based on participant-observation, using an approach adapted from James Spradley and David McCurdy's work on cultural scenes (1972). My study of Peruvian empleadas (domestic workers) and their relationship with señoras (women employers) was carried out during a total of six months of field research conducted in Lima, Peru, during three successive summers of 1995,1996 , and 1997. During my first trip to Lima, I conducted intensive interviews with eleven empleadas, complemented by interviews with four señoras. On my second trip to Lima, I 
concentrated exclusively on interviewing sixteen señoras. In 1997, however I modified my approach and did follow-up interviews with the señoras and the empleadas who had been my informants during the previous two years in order to fill-in some gaps in the previous accounts I had collected.

\section{Choosing the Cultural Scene}

As a Peruvian-American anthropologist of upper-middle class background, who has not only focused this study upon employed domestic workers, but had long ago participated in the señora role in Brazil and Panama ${ }^{1}$, I fit the category Lila Abu-Lughod refers to as "halfies ${ }^{2}$." "Halfies," according to Abu-Lughod, are those "people whose national or cultural identity is mixed by virtue of migration, overseas education, or parentage" (1991:137). Whereas traditional anthropological practice has been concerned with a fundamental distinction between the self and the other, this distinction becomes problematic for anthropologists, like myself, who choose to cross those boundaries.

Since halfies can encounter specific dilemmas in conducting research and analyzing data, I describe something of my background in order to place into correct context my position as both insider and outsider. This is important because in presenting the Other, as Abu-Lughod (1991) points out, I am also presenting certain relevant aspects of my Self.

I was raised through adolescence in San Isidro, an upper-middle class neighborhood in Lima. My father, a neurosurgeon, spent his days working away from the household, while my mother, a señora, stayed at home where she ran the household and organized the activities of the day with the help of the women she employed.

My sisters, brother, and I were not required to perform any household chores other than keeping our rooms in order. Most days, unless my father was performing surgery, we would all

\footnotetext{
1 Please notice I only mentioned two societies where I lived after I married. As I argue below, the fact that I never participated in Peruvian society as a full-fledged señora turned out to be a significant factor in my research.

2 Halfies is a term Lila Abu-Lughod borrows from Kirin Narayan.
} 
share lunch together in the dining room as a family. The meal was without exception cooked and served by domestic workers. At dinner, however, my sisters, brother, and I would sit in a separate area adjacent to the kitchen, supervised and served by the domestic workers, while our parents dined together in the formal dining room. During my childhood, I thought all families employed domestic workers in their households. Everyone we knew, all our friends and relatives, employed one or more domestic workers in their homes, and as a child, it never occurred to me that any home anywhere in the world was any different.

Eventually, I got married and left Lima. Subsequently, my husband and I lived in Brazil, Panama, and the United States. Having lived abroad, I came to appreciate some of the social differences between Latin America and the United States. Now I live in Florida, and like many women, I take care of household chores and children by myself, while also pursuing education. Although I had employed domestic workers after my marriage while living in Brazil and Panama, I had never experienced the señora/empleada relationship in Peru as a full-fledged señora. Nevertheless, I believed at the outset of my fieldwork that I could be relatively objective in investigating this topic and that I could fairly research the manner in which upper-middle class Peruvian señoras interact with their empleadas, as well as the perspective of the women serving them. In my actual field work however, I did experience certain intractable difficulties in interviewing informants from two different statuses and cultural backgrounds within the same cultural scene. The señoras were clearly situated structurally in a position in which I had shared significant commonalties, while the situation of the empleadas was obviously one of which I had very little personal knowledge. Nevertheless, each posed unique problems.

Hortense Powdermaker (1966) wrote of similar experiences while carrying out research in Mississippi with blacks and whites during the early 1930s. She related feeling that her life "was compartmentalized into Negro and white spheres" (1966:183). She lived in an all-white boarding house, while conducting research in both the black and white communities. In many instances, she agonized over her inability to maintain socially accepted forms of address and social etiquette. This was my experience as well. Thus, my approach in which I alternated 
between the two groups in successive field stays is consistent with the position outlined by Powdermaker in her discussion of participant-observation in power-differentiated, polarized situations. Some of my experiences are treated in the following section.

\section{Informants}

For my interviews, I used a tape recorder as well as hand-written notes taken during and following the interviews, which I recorded in a field diary and in my computer. All the interviews were conducted in Spanish. I promised each of my informants complete anonymity, so names have been changed, and some of the details have been disguised.

The decision to allow an interview was made by the señoras, both for themselves and their employees. I interviewed the empleadas during specific cycles of their working day in accordance with the wishes of the señoras of the house. I interviewed the señoras at their convenience. In some cases, I was allowed the opportunity to observe ongoing interactions between empleadas and señoras throughout the day; at other times, I saw the interaction while visiting, or during social gatherings.

After explaining to the señoras my intention to study the relationship between them and their empleadas, some of them offered to be my informants and were more than happy to allow me to interview their empleadas. However, they went on to say that it would be my task to approach the empleadas and ask them whether they would be willing to become my informants.

Because of my peer relationship with the señoras, my age, and my marital status, the empleadas saw me as a señora and initially were not willing to talk openly to me. To them I represented the "other side of the kitchen door," and they appeared to be afraid that I might tell their employers the things related to me, in spite of the fact that I promised to hold our talks in confidence. During my initial approach to the empleadas, I explained to them a little about my life in the United States, going to school, and running a household without any help. The empleadas let me know they were doubtful that I could attend university, do the housework, and 
cook the meals all by myself. Nonetheless, all the empleadas placed a high value on education, and although they seemed cautious, they said they would try to help me with this project. I also explained to them that I preferred to be called by my given name instead of the formal "señora." Even so, they always addressed me as "Señora Elena," and when I asked them why, they avoided providing any explanation on the subject.

Although it had been easier to approach the señoras at the outset, it was actually harder to conduct the interviews with them. As I have known most of my señora informants since we were children together, I did not have to explain anything about my life to them. They knew I attended university and did not have a live-in maid at home. However, because by background I am "one of them," they naturally assumed I knew how "things worked" around Lima. This could not have been further from the truth, and because of this interviewing the señoras proved to be more difficult and complex than I originally thought.

Some señoras were willing to talk to me openly; others would allow me to interview their empleadas, but became so evasive when it was their "turn" that I was unable to complete an interview with them. Still others would say a thing or two about their lives and the relationship with their empleadas, but the subject was obviously of little or no interest to them. In only 5 of 14 households was I allowed complete freedom to observe the empleadas throughout the day. Most señora informants fell back into their social roles, preferring that I visit their homes during the afternoons when the empleadas had finished with their work and the house was in perfect order. Some of the research reflected herein is based on my observations of the señoras while visiting their homes to interview their empleadas.

The señoras generally assumed I would be understanding of their problems and expectations regarding what they considered a buena empleada (good domestic worker). They talked freely about past and present experiences, abuses, and good and bad empleadas; however, they always made sure that their empleadas were not listening. 
The empleadas, on the other hand, only talked freely about past experiences with señoras they had worked for, for short or long periods of time. Their views about the señoras were always spoken in general terms. They were guarded about commenting on their present employers, and they also made sure the señoras were not listening. 


\section{CHAPTER II: BACKGROUND}

Peru is divided into three very distinct geographical regions: the coast, the highlands, and the rain forest. These regions are not only geographically distinct, but each also has "its peculiar internal divisions" (Cook, 1981:119). During the time of the Incas, the city of Cuzco, located in the highlands of Peru, was the center of the Inca empire. Noble David Cook suggests that during that time "perhaps 9 million people resided within the limits delineated by Peru's contemporary boundaries" (1981:116). There is no doubt that the conquest and subsequent colonization of Peru by the Spanish conquistadors had an enormous impact on the indigenous societies living in Peru at that time. The Spanish selected the site of modern day Lima, and founded their capital, the "City of Kings," in 1535.

Lima is widely known as the capital city of Peru, but it is also a department, a province, and a district. The political map of Peru is divided in 24 departments and one Constitutional Province. The departments are divided into provinces and these provinces, in turn, are further divided into districts.

The department of Lima is comprised of 11 provinces and 77 districts. The province of Lima itself contains 43 districts. According to the 1991 census, the province of Lima has $6,431,800$ inhabitants (Compendio Estadístico 1991-1992). My study was conducted in San Isidro, one of Lima's 43 districts.

San Isidro is one of the oldest districts in Lima. It is very sought after residentially and commercially, which makes it the most expensive land in Lima. The total population of San Isidro is 71,203 people, which includes the major concentration of upper-middle class people in the province of Lima (Compendio Estadístico 1991-1992).

\section{HISTORICAL PERSPECTIVE ON DOMESTIC SERVICE IN PERU}

Domestic service has been known in Peru since the arrival of the Spaniards in 1532. Although preconquest Andean society was highly stratified under Inca rule, "the position of 
women in preconquest Andean society was determined by the forms and culture of that society as a whole" (Burkett, 1978:102). Thus, the conquest and subsequent colonization of the Inca empire by Spanish conquistadors considerably altered the patterns of social rank and stratification of Andean society (Spalding, 1970:644). Inca society was controlled by a central state and three types of tribute payments were expected: agricultural goods, service, and textiles (Burkett, 1978:102). Tribute was a household rather than an individual obligation. From this viewpoint, the household was the basic economic unit of common people and the genderbased division of labor was the result of the division of labor within the household. Males were in charge of agricultural work and services to the State; while females were in charged with spinning and weaving for household use and tribute, as well as taking care of the children, cooking and preparing food, and participating in the harvest and planting of crops (Burkett, 1978:103).

Consequently the requests made by Spaniards for women to perform household tasks introduced an unknown element in Inca society (Burkett, 1978:109). During the Colonial period the patriarchal household became the foundation of Peruvian political, economic, and social life. Patriarchy rested on the fact that the Spanish Crown entrusted to the head of the household the responsibility to provide protection to "the members of his residence, whether or not these persons were related to him by blood and marriage" (Kuznesof, 1989:18).

During the early seventeenth century, the city of Lima received migrants from the various colonies of the Spanish realm who came to Lima to serve the Spaniards and religious people (Cook, 1968:XI). Servants comprised the second largest number of migrants in the city (Cook, 1968:XII). Kuznesof claims that "employment open to women in the Spanish colonies was frequently domestic" because occupations outside agriculture were few and poorly paid (1989:19). Indigenous women began working as servants to the Spanish because it offered them several advantages (Vergara, 1997). The Spanish Crown was obviously concerned about the treatment of female household servants, and notarial records dating from the sixteenth century indicate that contracts were drawn for services provided by indigenous women who were 
remunerated. Domestic servants received room, board, medicine, religious instruction, and two sets of wool or cotton clothing per year as well as small salaries which were fixed by law at twelve pesos for servants under eighteen years of age and eighteen pesos for women over eighteen (Burkett, 1975:218). These contracts rarely specified the responsibilities and obligations other than indicating the servant would serve the employer in and out of his or her household (Vergara, 1997). When women were hired to work as nursemaids or wetnurses, however, the precise nature of their work was made clear (Burkett, 1975:219).

James Lockhart notes that during the sixteenth century Spanish women comprised "a large minority of the settlers in Peru" (1994:169), and he further states that these women made "an important contribution to the development of local Hispanic society by educating those around them in the ways of their homeland" (1994:184). The social origins of Spanish women varied widely. There were sisters of fishermen as well as daughters of counts, although according to Lockhart, "the use of the dona drew a sharp line" between the female population. (1994:172). Regardless of social origin, these women arrived in Peru "as part of a family or were sent for by male relatives already in Peru" (Lockhart, 1994:174). The reason for immigration of the Spanish women was usually for purposes of finding a suitable partner for marriage or to reunite with a husband, and in this respect Lockhart asserts that "probably nine-tenths of all adult Spanish women in the country were married" (1994:174).

The Spanish Crown encouraged marriage, and as a result marriage was used as a method to establish alliances between local settlers. Lockhart argues that for Spaniards "an honorable, legitimate wife was essential" (1994:175), and that marriages, seen as strategic alliances, were arranged to augment the wealth or improve the social position of the men living in the colonies. Elinor Burkett (1978) suggests that married life afforded few distractions to Spanish women, but provided financial security and social approval. They were locked in their households, but were somewhat free to contract domestic help (1978:129). Spanish women

${ }^{3}$ Doña is an Spanish term of address that indicated high nobility, although Lockhart does note that this title was loosely used in Spanish Peru during the 1532-1560 period. 
taught their black and Indian servants to make beds, sew European clothes, and prepare Spanish foods. Spanish was spoken and learned in their homes.

The activities of indigenous women within the Spanish household became vital to the functioning of the household during the Colonial period. Burkett argues that the influence of indigenous women on the Spanish household may have been considerable if we consider that these women raised the first Creole or Peruvian-born generation. Indigenous women probably spoke to children in Quechua or other Indian languages, telling them stories that reflected their world views. At the same time, through their presence in Hispanic households as servants, they learned Spanish and became acquainted with Spanish customs, attitudes, and beliefs (Burkett, 1978:118). In their roles as servants, these indigenous women worked for and/or were supervised by Spanish women; they lived in their homes, cooked for them, and helped raised their children.

It was during the Republic Period (1895-1919) that domestic servants first received social benefits. However, the legislators of that period represented the oligarchy, and as a result "the legal codes tended to reassert the authority of the male head over other members of the household, especially women" (Kuznesof 1989:22). The state did not interfere with work performed in the private sphere. According to Kuznesof, the home was regarded as a "place of respectability, and as a result of the state's reluctance to pass laws to regulate the private sphere, employers gained "substantial power over the lives of their domestic workers" (1989:24).

Kuznesof concludes that due to "the colonial circumstances of conquest and caste/race relations, domestic service in Spanish America became an aspect of race and class subordination" (1989:31). Domestic servants were often denigrated because they were indigenous, poor, and ignorant. According to Martha Loza, Paulina Luza, Rosa Mendoza and Flor Valverde (1990) this is the source of paternalist, elitist, and racist prejudices that have persisted in Peru until today. 


\section{PERUVIAN SOCIAL STRUCTURE}

When the Spaniards arrived in Peru in the sixteenth century, they found various ethnic groups that had been unified by the political system imposed by the Inca, a minority Quechua ethnic group whose origins were recent (Fuenzalida \& Mayer, 1974). The Spanish categorized the different ethnic groups they encountered under a single racial category, "Indians." Lockhart (1994) claims that Spanish Peruvian society resulted from interaction between the long-term inhabitants of these early cities. Groups such as the encomenderos ${ }^{4}$, the artisans, Spanish women, blacks, and Indians had an important role in this development.

Fuenzalida and Mayer (1974) argue that at first the Spaniards' discrimination practices were not based on notions of biological superiority of certain racial groups over others. The interaction between the Spanish conquistadors and the indigenous peoples of the area were not established in terms of biological superiority, but on the basis of the moral, religious, economic, and political considerations advocated by the Spaniards of the time. The Spanish established specific hierarchical distinctions, for example, between the indigenous nobility and the common indigenous people. The indigenous nobility were given privileges and were assimilated into the new colonial bureaucratic structure, while the common indigenous people were destined to become serfs under colonial rule.

Fuenzalida and Mayer contend that the new Peruvian racial composition began to form from the moment of conquest. There were no prejudice doctrines prohibiting the free mingling of Spanish men and indigenous women. Beginning at the highest levels with marriages between ranking Spanish officers and the Inca nobility, legal marriages and unsanctioned relationships were soon prevalent at all social levels. By the end of the eighteenth century, three hundred years of miscegenation had resulted in a hierarchy in which social standing and economic positioning were of more importance than ancestry or physical appearance.

\footnotetext{
${ }^{4}$ An encomendero is defined as an individual who, for distinguished service, received a royal grant of the tribute and/or labor of Indians within a certain boundary, with the duty of protecting and Christianizing them.
} 
At present Apoyo Opinion y Mercado S.A. conducts an annual study of socioeconomic levels in Lima and classifies four main levels which range from category A to category $D$. The measurements used to identify predominant characteristics of these four socioeconomic levels are based on answers obtained from the heads of households to questions pertaining to such variables as place of birth, level of formal education, number of years of formal education, school attended by children living in the household, occupation, average and median monthly earnings as well as self-perception of class. It is interesting to note that race was assessed by the census taker and was not included within the body of the questionnaire. This is in keeping with the Peruvian Instituto Nacional de Estadistica e Informática (INEI) guidelines, which have not included "race" as a census parameter since 1940. Based on these observations, the racial composition of Lima is $20 \%$ white, $72 \%$ mestiza, and $6 \%$ indigenous, bearing in mind that this method of assessment is based entirely on the perception of the census takers. The following data shows racial component by socioeconomic level according to these data:

\section{Race of head of household (by observation):}

\begin{tabular}{lccrrr}
$\begin{array}{l}\text { Racial } \\
\text { Group }\end{array}$ & $\begin{array}{c}\text { Total \% } \\
\text { Greater } \\
\text { Lima }\end{array}$ & $\begin{array}{c}\text { \% within Socioeconomic Level } \\
\text { Upper \& } \\
\text { Upper-Middle }\end{array}$ & Middle & Lower & Lower-Lower \\
\hline Mestizo & 72 & 21 & 52 & 78 & 80 \\
White & 20 & 79 & 45 & 14 & 8 \\
Indigenous & 6 & 0 & 1 & 5 & 10 \\
Mulatto & 1 & 0 & 1 & 3 & 1 \\
Black & 1 & 0 & 0 & 0 & 1 \\
Oriental & 0 & 0 & 1 & 0 & 0 \\
\hline Total & 100 & 4 & 18.4 & 35.7 & 41.9
\end{tabular}

Source: Adapted from Apoyo, 1996

The futility of relying on this table is seen in Fuenzalida and Mayer's assertion that "in Peru a man's race has the aspect of an optical illusion. The higher a person is on the social scale the whiter their appearance; while the lower the ranking on the social scale, the darker their appearance" (1974:17). Furthermore, they argue that Peruvians subtly classify themselves and 
others in their society on the basis of diverse economic, social, and cultural elements to which biological ancestry takes a position of secondary importance. On this basis, physical appearance alone cannot be used as an indicator of social positioning or classification in contemporary Peruvian society. However, as noted by Fuenzalida and Mayer, "in the modern cities of Peru it is irrelevant to refer to an individual as white, indian, or mestizo other than in particular contexts. It is more common to refer to an individual in terms of upper class, middle class, or lower class" (1974:89). Likewise, Pierre van den Berghe and George Primov (1977) also state that:

Indians are clearly seen as inferior, but on sociocultural rather than racial grounds. If one tries to determine to what extent group distinctions are based on class (economic, occupational, and educational) characteristics as opposed to ethnic criteria (such as language, clothing, and other culture traits), it is evident that both sets of criteria are operative, but that socioeconomic and educational class criteria are more salient (1977:136).

Along the same lines, François Bourricaud further suggests that "Peruvians often have difficulty in identifying an individual as Indian, mestizo ${ }^{5}$, or cholo ${ }^{6 n}(1976: 350-1)$. Bourricaud contends that the Peruvian system of stratification "has never made use of strictly binary opposition between Indian and non-Indian" (1976:351). As a result, the unusual nature of the Peruvian stratification system can be attributed to the ambiguity of the "racial" factor which provides, according to Bourricaud, "a very complex symbolic function" (1976:351). The racial factor, therefore, links an individual to social status in agreement with the rules of a symbolic code.

In this respect Bourricaud argues that the term "cholo" comprises most of the ambiguities that can surround individual status. To start with, it has a powerful negative connotation and is generally used only when the person to whom it is being applied and who would probably be

\footnotetext{
5 A mestizo is an individual of mixed parentage, half Indian and half white.

${ }^{6}$ Social scientists have not arrived to a precise definition of the term cholo. Sarfati and Eisen extract from the various definitions the characteristics of the cholo and argue that a cholo "is marginal in the sense that his self-identity is new and insecure and his evaluation by others is problematic. He is highly mobile, geographically and occupationally" (1969:66). Bourricaud further suggests that "he is fluid and elusive." You never find him where you expect him to be and therefore you never know where to place him in the stratification system (1976:355).
} 
offended by it, is absent. It can only be used to directly address an individual as a sort of joke. The cholo emerges as a key character in a system that "neither encourages nor stresses mobility" (Bourricaud, 1976:357). In general we can say that a cholo is one who began as an Indian, but is not longer fully identified as such. The Peruvian stratification system is a mixture of very heterogenous elements combining rigidity with fluidity, and this juxtaposition results in the basic structural inequities within the current Peruvian stratification system.

The ranking for mestizos and whites in the system of stratification is reached by using data relating to style of life, family name, education, manners, and social poise. Sarfatti and Eisen argue that "while wealth is necessary, it is not of primary importance" (1969:54). They further suggest that criteria for social ranking may vary somewhat depending on the place of residence. In rural areas, the elite may be a relatively homogenous group made up of a few landed families, while in provincial urban centers, the elite may include professionals.

Regardless of geographical location, the elite consider the Indians to be a homogenous mass, while the Indians do not differentiate among the elites (Sarfatti \& Eisen, 1969:54).

Anthony Appiah (1996) argues that to talk about race, we must first understand what individuals mean when they use the term. He affirms that in the United States discussions about race inevitably presuppose some understanding of both culture and identity, and therefore, to the degree that race is associated with culture, there is some basis for preserving racial identity aside from whatever independent value racial labels may have when standing alone.

In Latin America, as noted above, emphasis is given to class rather than to racial and ethnic distinctions. Suzanne Oboler states that in ". . . Latin American countries, the discourse on race distinctions is much more gradated and each gradation is strictly related to the individual's status and social class position" (1995:157). Oboler contends that middle class Latin Americans first and foremost establish their class backgrounds to allow them to subsequently point out the considerable social distance between themselves and people of lower class background. Moreover, she argues that Latin Americans insist they are color-blind and will make every attempt to minimize the recognition of the effect that race has upon them in daily life. 
Oboler specifically cites a study conducted by Florestan Fernandes in Brazil in which he argues that "Brazilians' prejudice is rooted in their belief that they aren't prejudiced" (1995:130). Oboler holds that this finding can be extended to depict the varying degrees of racism prevalent throughout Latin America. Similarly, and concurring with the Brazilian study, Juan Carlos Callirgos (1993) found during a series of interviews conducted in Lima that Peruvians assert there is no racism in Peru and that the racial factor does not influence their daily lives. Callirgos notes that many of the people interviewed demonstrated resistance to speaking about race or racism. Some changed the subject, some stayed silent or said they did not understand the question, while others laughed nervously. Callirgos concludes that race is a taboo subject in Peruvian society (1993:199).

\section{MIGRATION TO LIMA}

In 1940 the rural areas of Peru contained $65 \%$ of the total population of the country, while the urban areas contained only $35 \%$ of the population. By 1981 these percentages were reversed. Today $65 \%$ of the population of Peru is concentrated in urban areas, with $35 \%$ remaining in the rural areas. Correspondingly, during this same period, in the province of Lima, the population increase was considerably higher, having changed from $8.6 \%$ of the total Peruvian population in 1940 to $26 \%$ of the total population by 1981 (De Soto, 1986). Recent estimates suggest that Lima now holds $30 \%$ of the total population, and according to Barnechea (1995) Lima absorbs 400,000 migrants each year. This phenomenon of mass migration affects every aspect of the political, social, economic, and cultural structure of the city.

Migrants leave rural areas throughout the country and move to Lima in search of better economic opportunities, access to education, or to escape situations where the rural family cannot feed or care for all their children. This migration has caused a spectacular demographic explosion in the former boundaries of metropolitan Lima, and has caused enormous social and economic transformations. José Matos Mar (1988) uses the term desborde, meaning "overflow," to describe the phenomenon. He asserts that almost $80 \%$ of Lima's population live in marginal 
conditions in areas called asentamientos humanos marginales ${ }^{7}$, while $20 \%$ are concentrated in residential neighborhoods of the middle and upper classes (1988:71).

Matos Mar has chronicled the existence of two different "Perus." One, the Peru Oficial (representing the legal identity, bureaucracy, institutions, business); the other, the Peru Marginado (representing the informal tier of society, the economic and social black market, Indian farmers), the duality of which has forged the current Peruvian social identity (1988:99).

The majority of the empleadas working in Lima are migrants from rural areas, especially the Andes. They were attracted to Lima by its reputation for wealth and opportunities. They had wanted to go to Lima to study, or to work and send money back home to help their parents. Migrants, therefore, do not necessarily reject their Andean hometowns, rather their move to the urban areas is often seen as a temporary situation "from which specific advantages are sought" (Bourque \& Warren, 1981:198). Susan Bourque and Kay Warren further suggest that the process of migration should be "understood as one aspect of the process of family network construction" (1981:198). According to a poll conducted by Loza et al. in Lima, about two-thirds of the domestic workers migrate from the Andes (67\%), approximately one-quarter from the coast $(25 \%)$, a minimum from the rain forest areas (5\%), while (3\%) did not respond (1990:29).

I conducted fieldwork in 14 households located in the upper/upper-middle class residential district of San Isidro. This area has not been directly affected by the population "overflow," and although it continues to experience many changes, its growth has been relatively slow. As the wealthiest neighborhood in Lima, San Isidro also has the highest consumption of agua potable (water) per person annually, and unlike other areas has all basic services including water, electricity, and sewage. This is in stark contrast to the asentamientos informales or

\footnotetext{
7 The term asentamientos humanos marginales falls within the category of asentamientos informales coined by Hernando de Soto (1986), who states that in the last four decades the urban space in Lima has grown $1200 \%$ as a result of migration. This growth has been largely informal as people have constructed towns marginally or against legal dispositions. The asentamientos informales are the opposite of traditional 'legal' urbanization. These have been created through invasion, where the land is first occupied by squatting, after which comes the construction of houses. Only at the end of this informal process do the new inhabitants obtain ownership of the land on which they now live.
} 
squatter settlements in which many empleadas maintain their secondary home which they visit during their "time-off." There, basic services if any are few or altogether absent.

Some of the empleadas I interviewed hoped one day to be able to buy some land to build a house, while some were in the process of slowly constructing houses, and others already owned a house. However, all my empleada informants had family or friends they could visit who lived in the asentamientos humanos marginales located on the outskirts of the city. It is to these new towns or slums, lacking basic services, where the empleadas of San Isidro go on their day of salida (day-off). The empleadas therefore, can easily appreciate the enormous difference in the living conditions between their homes and those of their employers. But the contrary is not true. Neither I, nor any of the señoras, have ever visited any asentamientos informales. We know of them only from a distance, often passing them while driving on the way to the beach. 


\section{CHAPTER III: CASE STUDY}

\section{THE PARTICIPANTS}

\section{The Empleadas}

The 11 empleadas in my study had migrated to Lima from various parts of Peru; seven from small communities in the Andes and four from the coast. The empleadas from the Andes included Monica (Cajamarca), Cristina (Arequipa), Teresa (Huaraz), Cecilia (Yauyos), Juana (Huanuco), Carmen (Arequipa), and Pepita (Cuzco); and from the coast Charo (Chimbote), Rosa (Lurin), Flora (San Juan de Miraflores), and Dolores (Piura).

Most of my informants left their towns with a tía (aunt) or madrina (godmother) to come to Lima to finish their studies. All my Andean informants had finished primaria (elementary school) in their rural towns and wanted to go to Lima to finish secundaria (high school). The ages at which my informants left their towns ranged from 10 to 18 years old. Each of my informants expressed how much they valued improving their level of education, and that was the main, but not the only reason to leave their natal families.

The "aunt" or "godmother" need not necessarily have been a relative of the family, but was usually someone, usually a woman, from the same community returning from Lima for a visit, bringing with them stories of the vastly different life of the city. The "aunt" typically promised the parents to send the girl to school in exchange for help in her home or place of work. The parents generally placed implicit trust in the "aunt" or "godmother," and after speaking to their daughter everything was "arranged" and a date agreed for departure to Lima. The case of Monica illustrates life in a rural Andean town and how the opportunity to go to Lima to study and work were presented:

Monica left her town at the age of 18 . Her father had some land in a valley where he cultivated coffee and bananas mainly. He also cultivated quinoa, beans, wheat, and barley in the upper parts using andenes (platform system). The family had two horses, some chickens, guinea pigs, and turkeys which they "ate sometimes and sometimes they sold." Wealth was measured in terms of land and animals. Somebody with ten cows would be considered wealthy. She explained that in this area everybody was equal, there were no hacendados (large farm owners). 
Monica had finished primaria (elementary school) in a small country oneroom school and wanted to come to Lima to continue her high school studies. This opportunity presented itself when her "aunt" came for a visit and told her parents that she knew of a señora in Lima who needed a chica (young girl) to help around the house. Monica accompanied her aunt to Lima after being told she was going to help the señora with the household chores, in return for propinas (tips) and the opportunity to go to school (Field notes, 1995).

Once in Lima, these young girls frequently discovered that their parents had been deceived. All of my informants stated that they assumed their new responsibilities without question. They usually went to live and work in the asentamientos informales or lower-class neighborhoods where their first shock was to discover that "help" meant doing everything around the house. Second, they soon discovered that they were not able to go to school as promised. They were given various reasons for the broken promises of schooling, such as being told they were too young, or "how will the señora go to work if you go to school."

Their most shocking finding, however, was the treatment given to them by their employers in Lima. Monica's case is representative of the transition from rural life to city life experienced by my informants:

Monica was shocked when at lunch time, she set up the table and the family sat to have lunch. She did not understand why she could not sit in the same table with her employers. She asked her aunt and she replied that they were going to eat in the kitchen because 'that is the way it is.' Monica needed an explanation and her aunt didn't give her one. At that time she thought people from Lima were mean, como la tratan a uno (how do they treat us) (Field notes, 1995).

The realization of differential treatment came as a complete surprise to my informants who came from small agricultural communities where they claimed everybody was friendly, cooperative, and socially equal. They found people from Lima to be cold, rarely friendly, selfcentered, and above all racistas (racist). Many informants also said that following their arrival in the city, the attitudes of their aunts/godmothers toward them changed. They frequently became indifferent and sometimes abusive. It was apparently not uncommon for my informants to be verbally and physically abused by their aunts/godmothers and, in some cases, by their aunts' families. 
The abuses went even further. Often letters from parents were intercepted and remained undelivered, salaries were not paid, and empleadas received only food and lodging in return for work. Even though sometimes a small propina (tip) was given, this was not nearly enough for them to use to regain their freedom, and their poverty further deepened their isolation.

Two of my informants had been sexually molested by their previous employer's husband or sons, two others had previously been physically abused (beaten), and three had not been allowed to leave a previous place of work unaccompanied at any time. Three of my informants stated they had not been allowed to go to school as initially promised.

Bunster and Chaney state that 'the 'Iordly dream' of Spanish colonial Peru has never been relinquished by Peru's dominant classes, only scaled down" (1985:28). This makes it possible for even lower-class families to have at least one empleada. For my informants, it was common to be made fun of, humiliated, and to be called by the derogatory term, chola. The empleadas themselves describe a chola as someone from the Andes, a recién bajada (somebody that just came down from the mountains). They were usually called cholas by the family they worked for, who were usually lower-class limeños whose own parents had come from the Andean provinces. Cecilia explained to me:

They treated me as if I wasn't from their family, as if I was a stranger, as if I wasn't from the same town. They called me chola. I didn't receive letters from my parents. One of my aunt's sons pulled my hair because I disobeyed him. I did not iron his pants, and his mother also screamed at me if I didn't do things right, but I never had the time to finish my chores around the house... (Field notes, 1995).

Eventually, often through the help of actual kin (aunts or sisters) already working in Lima, they leave these places to seek employment in higher class neighborhoods. Some of my informants put up with these abuses in order to finish school; others just gave up the notion of schooling altogether. However, once they were able to leave this initial situation, it became imperative for them to find a new job to support themselves, as there was seldom any hope of economic help from their parents. They needed to find a place to live, and the obvious solution 
was to find a job as an empleada, which would provide them with housing, food, and a salary. All my informants had worked in various lower-class neighborhoods before finding their present jobs in upper-middle class neighborhoods in Lima.

My empleada informants got their present jobs through relatives or friends who were also empleadas. For example, Teresa is the niece of Rosa and they both work in the same house, where Rosa is the cocinera (cook) and Teresa, the ama (in charge of small children). Teresa was also my youngest informant ( 21 years old), while Rosa was the oldest ( 39 years old). All of my other informants were in their twenties, with the exception of Cristina and Juana, both in their early thirties.

\section{The Señoras}

The señora informants were 20 women whose ages ranged from 26 to 38 . Fifteen were married at the time of the interviews and five were divorced. Most of them have children (16). Half of my informants do not work outside their homes and among the other half, some have either full-time or part-time positions as lawyers or managers. A few run their own businesses. Regardless of their marital and employment status, they all lead very active social lives. The señoras I interviewed did not necessarily know each other, although they all frequent the same social circles.

The señoras in my sample belong to the upper and upper-middle classes of Lima. From the time of my first field interviews, they expressed a great interest in sharing their views about people belonging to their same social class or belonging to "other" classes, rather than discussing their views on domestic service. Establishing social identity appeared to be a critical issue for the señoras. This is supported by Pierre Bourdieu's observation that "social identity is defined and asserted through difference" (1984:172). According to Bourdieu, in the social space of everyday life, the points of view of people belonging to different classes will "depend on their 
position within it" (1984:169). Likewise, "differences in bearing, differences in gestures, posture and behavior" will reveal an individual's relationship to the social world (Bourdieu, 1984:192).

There are, according to the señoras, certain identifying features common to gente como uno ${ }^{8}$ (people like us), which allows them to know whether someone belongs to the same social space or not. In this respect, the markers they use are in many ways subtle and in other ways not so subtle. For example, the main identifying marker for my informants is a family's last name. All of my informants agreed that "money is irrelevant" as there are people like them that have important family names but no money. While family name seems to be the most relevant marker to establish class identity, the señoras spoke of other common characteristics of people like them. Next in importance seems to be what the señoras call educación, a term that when literally translated into English means "education." For the señoras, however, educacion, means "to have good manners," to have roce social (social poise), to have clase (class), which simply means one should know how to act in any upper-class social situation, including using the right cutlery when eating, dressing the proper way, speaking proper Spanish, etc. This should not be confused with "level of education" meaning years of schooling. Other important markers in establishing class identity for the señoras are the neighborhoods in which they live, the schools they have attended, theoccupations of their fathers and husbands, and to a certain extent their economic standing. In order to live in one of the acceptable neighborhoods there needs to be a certain income level that will allow them to comply with the standards of belonging to the upper classes.

Bourdieu notes that "manner, by definition, only exists for others, and the recognized holders of the legitimate manner and of the power to define the value of manners---dress, bearing, pronunciation---have the privilege of indifference to their own manner" $(1984: 95)$. This emphasis on manners "gives the recognized possessors of the legitimate manner an absolute, arbitrary power to recognize or exclude ${ }^{n}(1984: 95)$. In their conversations, the señoras constantly insinuated class distinctions by using terms from a specific lexicon to include or

${ }^{8}$ Gente como uno is commonly referred to in upper class circles by the acronym "GCU." 
exclude people from their circle. These terms include pituca ${ }^{9}$, huachafa, and chola.

The term pituca, which is mildly pejorative, nevertheless refers to someone that belongs to the upper or upper-middle classes. One of the señoras stated that pitucas:

are extremely frivolous, they are always perfectly dressed, everything matches to perfection. They believe they are (socially) better than everybody else and are particularly indifferent to people that do not belong to their social class. In general, pitucas are constantly talking about money, so they are usually rich (Field notes, 1996).

Nevertheless, even though all of my informants claimed to dislike pitucas, they stated that it is perfectly acceptable to socialize with them as they belong to their same social class. Some señoras acknowledged that some women gave the impression or were thought of as pitucas, but that the reality was different "once you get to know them" they are not as frivolous as people may think.

The term huachafo indicates aspiration and implies a hideous attempt to imitate the manners and ways of the upper classes (Adrianzen, 1990:17). According to the señoras, the term huachafa, is used to refer to lower middle class women who have "no class," and yet who try very hard to demonstrate to others through newly made money that they belong. For the señoras, however, this is almost impossible because huachafas are not like them, and this will surface in their manners, poise, way of dressing, and the decoration of their homes. Usually the personal appearance of huachafas and the presentation of their homes is not subtle, because, as the señoras argue, huachafas have no taste. For the señoras taste is acquired in the cradle. So even though they may have money, huachafas are not accepted by the señoras because they do not share the same social background. They look different and speak using words that are not acceptable in upper and upper/middle class circles. For example one of my informants pointed out that an upper or upper-middle class woman refers to hair as pelo while a huachafa refers to

${ }^{9}$ Rafa Leon, a linguist who writes a bi-weekly column in a popular magazine under the pseudonym of China Tudela, has developed this personality as the "ideal pituca." China often refers to the "GCU" in her attempt to establish social distance between herself and the lower classes whom she despises. As a result of the popularity of this column, GCU has become an upper class buzzword. 
hair as cabello. There are, according to the señoras, other key words that make this recognition possible, although the señoras emphasized first and foremost that a huachafa's lack of taste was difficult to overlook and accept.

Bourdieu claims that taste or manifested preferences are "the basis of all that one has...and all that one is for others, whereby one classifies oneself and is classified by others" (1984:56). Thus, Bourdieu suggests that "aversion to different life-styles is perhaps one of the strongest barriers between the classes," noting that class endogamy provides ample evidence (1984:56). Furthermore, the emphasis given to exquisite personal and home appearance confers a unique excuse "to experience or assert one's position in social space, as a rank to be upheld or a distance to be kept" (1984:57).

The third term is chola. This term has multiple meanings depending on who is using the term. As Bourdieu suggests, "language is both common to the different classes and capable of receiving different ... meanings ${ }^{n}$ (1984:194). For the señoras, this term means somebody of mixed descent. The term chola is derogatory and is used to refer to anybody that does not belong to their social class. Empleadas are then, by definition according to the señoras, cholas. The señoras were emphatic in stating that they would never call them by that term to their faces or within earshot. This term is only used in the presence of people with similar social backgrounds or people they perceive to be "like them" to refer to people of lower social and economic status, or "not like them."

The señoras in my study are daughters of, married to, or divorced from wealthy successful professionals and entrepreneurs and belong to the urban upper-middle class of Lima. Neither they nor their husbands belong to what is sometimes described as the oligarchy of Peru, a concept that is usually associated with the term "elites' in Peruvian society (Sarfatti \& Eisen, 1969). Magali Sarfatti and Arlene Eisen define the oligarchy as "constituted of a small group of familial clans" consisting of forty families "whose power base is chiefly in the Coast" (1969:258). The señoras define themselves as upper-middle class because of their family names, socioeconomic status, and shared values, which in fact reflect the ideologies and values of the upper 
class or oligarchy of Peru. Dennis Gilbert's fieldwork in Lima among upper class families suggests that these families have "limiting rules of membership" and "possess an internally and externally recognized identity" (1981:754). Gilbert further asserts that descent group membership is given genuine importance within upper class circles (1981:755).

The señoras had all been born in Lima, had all attended private schools and in most cases private universities, have always lived in upper class residential neighborhoods, and had all married within their same social circle. Until marriage these women lived with their parents in homes where their mothers were responsible for dealing with the empleadas. These same women became responsible for dealing with empleadas upon getting married and leaving their family homes, as this is the expected division of labor by gender in the upper and upper-middle class Peruvian household.

\section{WORK AND RESPONSIBILITY}

\section{The Señoras' Perspective}

Without exception my informants stated that their most important social roles were those of wife and mother. To be able to fulfill these roles successfully, the señoras are completely reliant on the help of empleadas. Although the señoras take responsibility for "running the house," this is clearly limited to a supervisory role and does not entail performing actual housework. The señoras expect their houses to be in perfect order at all times, and to achieve this perfection, they are totally dependent on the labor of empleadas. As successful wives and/or mothers, the señoras are expected to maintain balance and harmony in their households which in their belief may only be achieved by the outward appearances of perfectly clean households and well-behaved children. The maintenance of appearances is not only expected by their husbands, but is also the way the señoras judge each other. As such, each of the señoras interviewed clearly expressed the importance of maintaining these high standards. 
The señoras are in charge of the household routine, and organize the activities for the day for everyone other than their husbands, they plan menus, and choose the clothes their children will wear. They expect their houses to be immaculate at all times, as it is common to have unexpected visitors drop by any time after 11 a.m. For the señoras the empleadas represent an integral part of their lives, and are regarded as a necessity rather than a luxury. When noting the aversion they felt towards household chores, they all stated that it would be "very difficult to live without empleadas to help them around." One of my informants, Señora Lorena stated that "it would be impossible to run a house and lead a social life without empleadas." Therefore, for the señoras, to have a buena empleada (good maid) is of utmost importance. A buena empleada gives them freedom, allowing them to pursue careers, active social lives, and even freedom to be able to go away on trips leaving their households and children in good hands. According to one of my informants:

a buena empleada is someone who likes to do everything in the house, is honest, has a positive attitude at all times, does not answer back, and likes to entertain and 'educate' children (Field notes, 1995).

As a result, the señoras have certain requirements in mind when they hire empleadas. They stated that they prefer to hire women from the north coast of Peru, because women from this area are believed to have what the señoras call buena presencia (good presence). Used in this context, there is no doubt that "good presence" is an invidious term that refers to ethnic identity. Buena presencia insinuates an aesthetic aspect that implies the absence of specific racial features (Callirgos, 1993). My informants claim to dislike hiring women from the Andes region because they were often obviously indigenous in their manner and appearance. The señoras stated a preference for hiring women whose appearance and manner was not indigenous, because these women are assumed to speak poor Spanish and are considered not clean. Ironically, almost all the women they employed came from the Andes. Señora Andrea clarified that empleadas from the Andes have "bad habits and usually smell bad," even though, according to her, there are exceptions. She acknowledged that one of the empleadas working in 
her household is from Huancayo (a town located in the Andes), although she admitted that "this empleada is exceptional in every respect, including taking a shower every day."

\section{Hiring an Empleada}

According to señoras, the process of hiring an empleada can be accomplished in different ways. The señoras were in agreement that the most favored way to hire an empleada is through the recomendacion (recommendation) of empleadas working in the households of friends or relatives. The señoras will contact their closest friends or relatives to find out if any of the women currently working in their households have a sister, a cousin, or a friend that would like to work. In this way, the señoras feel that prospective empleadas have a recommendation from somebody they know and therefore can be trusted.

If this is not possible, there are agencies that provide this service for a fee. Generally, this method is not a favored recourse and it is disliked by the señoras who claimed, "you never know what type of empleada you will get." For a fee, the agency will provide an empleada, but it is not responsible for whatever "happens" once the empleada starts working in the house. Things that may "happen" include limpiar la casa (cleaning the house), which ironically means that everything of value may be stolen.

Another way is to put an advertisement on the newspaper, preferably "El Comercio," in which case written (verifiable) recommendations from previous employers are needed. In fact I remember seeing as a child notices placed in front windows stating "Se necesita muchacha" (young girl needed; i.e., maid needed) in lieu of using the newspaper.

According to the señoras interviewed, empleadas may be hired to hold various positions within the household. In the hierarchy of empleadas, the niñera (nanny) has the highest ranking. The responsibility of the ninera is to take care of the newborn baby and she is not required to perform any other household duties. Ideally, the niñera arrives at the household the same day the mother and baby arrive from the hospital and sleeps in the same room as the newborn. If 
the mother is breast-feeding the child, the ninera wakes up her employer and waits while she feeds the baby, and then brings the baby back to the bedroom, changes the diapers, and puts the baby back to sleep. Nineras usually stay in the household until the baby turns one year of age at which time they may be asked to leave, although niñeras may stay in a household for many years if the señora is planning to have a big family. In this case, the niñera will successively take care of each infant until another newborn arrives.

Niñeras are soon replaced by amas. Amas take care of all children over the age of one, but they do not enjoy the same prestige given to a niñera. Because of this, not only do they earn less money, but they are also expected to help with other household duties, usually cleaning. Amas may stay in the household for a longer period of time than nineras, and this time factor allows closer relationships to develop between child and caretaker.

Cocineras (cooks) are usually only in charge of meal preparation and sometimes laundry and ironing. Their ranking in the household is higher than that of amas for several reasons. First, they enjoy a higher degree of freedom than amas do; and secondly, they can replace amas on their day-off. In this way, cooks are more versatile workers than other empleadas.

In the ranking of domestic service, an empleada de servicio (all-service maid) has the most difficult working situation. She is expected to perform all household tasks including cleaning, cooking, washing, ironing, as well as taking care of the children in the household. The number of varied daily responsibilities within the household implies that an all-service worker must dedicate an enormous number of hours and constant commitment to her work. This continual work-load leaves the empleada de servicio with little or no time at all to rest until all household tasks have been completed, usually very late at night.

My informants were employed as ninera (1), ama (4), cocinera (3), and servicio (3). 


\section{The Empleadas' Perspective}

The empleadas were divided in their opinions concerning the amount of their work. Two of my informants believed it was right for the señoras not to do anything around the house, three stated "that's the way it is," while the other six informants could not understand how anyone could be so lazy. Monica, an empleada de servicio, for example, dislikes the fact that the empleadas have to do everything around the house and also constantly have to serve the other members of the household. She believes that "the señora should take care of her own things." She finds it difficult to understand how the señora can hire somebody to take care of her house and later ignore or pretend not to notice the amount of work in the household.

Of all my empleada informants, only one goes to school now. Cecilia finished high school, and has now a title as Auxiliar de Contabilidad (Accounting Assistant). She wants to go to university, but failed to pass the admission test; however, she intends to try again. In the meantime, she continues to study Computación (DOS, Lotus, and Quattro Pro). Cecilia would like to stop her work as an empleada to become an Accounting Assistant. However, the people she graduated with get paid approximately 135 to 157 dollars a month, which is not nearly enough money to afford a house, food, and pasajes (fares).

My three older empleada informants have given up any idea of going to school. Their expectations have changed and now their main concern is to be good providers for their children, as none of them want their children to work as domestic workers. One of my informants, Juana, has two children, ages 12 and 10, and was expecting her third baby. She would have liked to go to school as she feels some education could have provided her better job opportunities. Juana also told me that her children are embarrassed by her empleada position. Her children attend a colegio estatal (state-owned school), and have promised Juana that one day they will pay back her mother's efforts and sacrifices. Juana has Sundays off, and during this time she does her own household chores and spends time with her children. 
The rest of the empleada informants, although not allowed to go to school by the señoras where they worked, still have some hope of being able to attend school some day. They felt too uncomfortable to ask the señoras for permission to go to school, as they had been hired sin colegio (on the understanding that they would not be attending school). The other reason for not continuing their studies is their economic situation. They either sent money remittances back home, or helped support other relatives in Lima. Teresa told me that she had heard from Juana that Señora Lorena has already said "no" before to other girls, and Teresa, therefore, assumes it would be a waste of time to ask. Charo, who works in the same household, told me, "I want to get ahead; I want to study and work; I want to be a nurse; I don't want to be an empleada all of my life. If the señora doesn't allow me to study, I will find another job."

Sometimes, another reason for not going to school is that during the summer the employers go to their beach houses and bring their empleadas with them. For the empleadas it is very difficult to find transportation back to the city to attend school. Monica was not told in advance by the señora that they would be spending three months at the beach. The señora assured her that she was going to love the beach, but Monica said she hated it. She had never seen the beach before, and was expected to accompany and take care of the children while they played near the sea. She thought the sand was dirty, so she quit. Pepita and Dolores, on the other hand, do not mind going to the beach, even though they acknowledged having more work since there are more social gatherings at the house where they work. Pepita told me that she hated going in a small boat to the yacht to leave ceviche (a Peruvian dish consisting of raw fish marinated in lemon juice) for her employers and guests.

In February of 1996 (which is summer in Peru) I went to Lima and while there, was invited to Señora Maria Eugenia's beach house. I remember Señora Maria Eugenia calling Pepita from her cellular phone and asking her to bring ceviche to the boat. Pepita carried the food, plus plates, cutlery, and napkins. She was brought to the boat by a worker of the "Yacht Club" to leave the things, and then went back to the house to continue with her work. Pepita doesn't have time to swim due to the amount of work she is expected to do. In fact, even if she 
had the time she wouldn't do it because there are mucho gringo (she explained to me she meant there were too many white people). She said she was embarrassed to swim in front of the señores and their friends. When I asked her why, she said she is too fat, and that the "señores son señores"going to the club where empleadas were not allowed to sit and eat, and that they should never put themselves "de igual a iguar" (on an equal basis) with the señores.

\section{SOCIAL DISTANCE}

\section{The Empleadas' Perspective}

Although none of the empleadas had ever been called offensive words such as chola or serrana by their current employers, the social distance differentiation was subtly applied by limiting access beyond the kitchen door unless required for work. Monica mentioned the fact that empleadas are not allowed to sit on the household furniture, or share the dining room table with the señores indicates that empleadas hold an inferior status within the household. Monica said "algo asi como un perro" (something like a dog). Flora also spoke to me about the difference in the places where she and the señora sit. Flora acknowledged to me that she considers herself a chola because her parents come from the Andes. Flora also stated that while she had never been called chola by anyone in the household, the obvious social differentiation she was clearly subjected to reveals what the señores thought of her, and she claims that she should be called chola to her face.

The empleadas had stories to tell me of their experiences with racismo (racism). Most informants indicated the harshest discrimination was felt at school, followed by hearing limeños in the street call other people like them $\operatorname{cholos}^{10}$, guanacos $^{11}, \operatorname{serranos}^{12}$, sucios $^{13}$. However,

10 Cholo has multiple meanings, as discussed previously.

11 Guanaco is an animal of the same genus as the llama. This term is used by non-Andean peoples as a derogatory description to refer to Andean people.

12 Serrano refers to someone from the Sierra region and is typically used to refer to Andean people.

${ }^{3}$ Sucios means "dirty," and in this context refers to somebody with poor personal hygiene. 
they all assured me that they had never been called names by their current employers.

Most empleadas indicated that while not understanding the social differentiation made between themselves and their employers in their initial jobs in lower-class districts, they readily accepted the differences between themselves and their new employers in wealthier areas of Lima because they realize their new employers not only have more money, but a higher level of formal education. My informants also indicated that while their lives are 'better' in the residential neighborhoods of Lima, the differentiation between themselves and the members of the household is more distinctly marked than ever. The only reasons for their coming out of the kitchen area are to serve members of the household or to clean the house. The exceptions to this rule are the cases of niñeras and amas who may sleep in the same room as their charges while conforming to the other spatial limitations expected of empleadas.

The empleadas constantly alluded to the fact that there are two social levels; one in which the señores and their friends belonged, and their own. They said they were constantly aware of this social distinction and understood the impossibility of attaining social access at the same level as the señores. Their understanding of this situation is clearly defined by the comment of Rosa who said that "los señores se dan su lugar" (employers know their place) and "nosotros nos damos el nuestro" (and we know ours). Most informants indicated that it is better to keep their place. Cecilia also claimed that "nosotras tenemos nuestro sitio" (we have our place), and continued by saying that "we are empleadas and they are señores." Juana told me "como me voy a igualar a los señores, son mas decentes que nosotras" (how can I be on an equal basis with the señores if they are more decent than us) and added "nosotras somos decentes pero mas humildes" (we are also decent but more humble). Margo Smith (1971) suggests that the term gente decente is indicative of respect and social superiority and is used to refer to the middle and upper classes while gente humilde "although never used as a derogatory term, always refers to the lower classes. 
The four empleadas working in one household talked to me while they were having lunch in the kitchen at 3:30 p.m. I had already had lunch at 2:00 p.m. in the dining room with the señora. Rosa, a cook, encouraged Charo, an empleada de servicio, to speak to me, telling her that I could be trusted. This lunch took place towards the end of my first fieldwork and the empleadas finally seemed relaxed in my company. The four of them agreed that they feel comfortable with each other because they knew they belonged to the "same class level."

Without exception all my empleada informants claimed that the only difference between them and their employers was the fact that the señores had more "money." Money, according to my informants didn't give you happiness, the common assumption being that poor people were happier than rich people. As Rosa told me, "todos tenemos problemas ricos y pobres, la plata no hace la felicidad" (we all have problems, rich and poor, money does not bring happiness).

Cecilia told me she tells her friends not to feel ashamed or embarrassed about not having money because rich people are unhappy and spend their time fighting. The reason, Cecilia said, is that the señores spend too much time taking care of their bienes (properties and goods) and didn't have enough time to spend with the señoras. However, my informants claim that money is the only difference between them, and their employers seem to be inconsistent with their prior statements about "decent people" and their level of education.

\section{The Señoras' Perspective}

The señoras made a clear distinction between people like "them" and people "not like them." The use of words such as "nosotros" and "gente como uno" is revealing in this respect because they provide a clear insight into the importance upper-middle class women in Lima give to social space and social class. My informants emphasized certain markers such as the importance of a family's last name, attending the same private schools and universities, living in the same neighborhoods, and going to the same parties, clubs, and beaches that clearly identified them as belonging to the upper classes. Most importantly, they emphasized the 
differences in education, which we might remember, does not refer to formal education but to "modales" or manners, social graces, and social poise.

The señoras informed me that they help their empleadas in various ways. They believe that empleadas need to superarse (improve their education), and to that end they registered them in cooking and baking classes, or in courses to learn how to properly set tables for special dinner parties. Señora Maria Fernanda believes it is important for an empleada to learn "social etiquette." The señoras told me that even if an empleada goes to school or university and earns a degree, it will be impossible for her to find a good job, as high-level jobs do not only require a high level of "real education," but also buena presencia (good presence) and buenos contactos (good contacts) within the upper classes. Consequently, my señora informants are not supportive of their empleadas' aspirations to go to school to superarse (get ahead or improve their social and economic standing). They prefer empleadas sin colegio (maids that are not students). It is common to see in the employment section of "El Comercio" avisos (want ads) stating "Se necesita muchacha, sin colegio" (no students need apply).

The señoras explained to me the differences between their private school education and the public school system in Lima. Private schools are always bilingual, university-oriented, and competitive from the beginning. Children four or five years old are expected to take an admission test, and once accepted, they will go to school with the same children (also upper and upper-middle class like them) for the rest of their schooling years. On the other hand, colegios nacionales (state-owned schools) have to accept children without any admission test, are usually technically oriented, and teach all their courses in Spanish. Empleadas in Lima aspire to attend colegios nocturnos (night school) where the academic level is deemed low by the señoras. The colegios nocturnos are never considered as an alternative for the upper/upper-middle classes of Lima as these schools have poor academic levels due to the fewer class hours, and lack of libraries and basic supplies. These differences, based principally on "economic access," give the upper and upper-middle classes an almost matchless head start. 
The señoras agreed that domestic workers should always eat in a separate area and only after the family had finished eating. Different opinions were offered as to the reasons why this happened. One of the señoras argued that it was related to "form rather than substance," but overall the argument given was that empleadas lack decent table manners, and this was unacceptable to the señoras. Only one señora explained that if the empleada has been with the family for many years then it might be acceptable to have her at your table under special circumstances. However, from experience in the field, I would agree that this only happens in exceptional circumstances when the family is alone and never when there are guests present.

Bourdieu also claims that for the upper classes, form takes priority over substance, while the reverse seems to be true for the lower classes (1984:197). In these two antagonistic approaches to the "act of eating" there is, according to Bourdieu, "no neutral viewpoint" (1984:199). In the señoras' world, the division between the private and public realms seems to be non-existent. Particular emphasis is given to form and manner, and this attention to propriety cannot be fully explained by the presence of strangers in the house, either empleadas or guests (Bourdieu, 1984:196).

The señoras were in agreement as to how social distance is maintained between them and the empleadas. As a result, since the señoras consider empleadas to be different from them, there is no possibility, as Callirgos argues, to establish reciprocal relationships between them. The responses given by the señoras during the interviews always pointed to the differences between themselves and the women employed in their households. Consequently, the señoras expressed how important it was for them to have empleadas address them and their husbands respectfully at all times. The señoras expected empleadas to look well presented and wear uniforms while they work, and to eat their meals only after the family had been served and had finished eating. Furthermore, and without exception, the señoras required that empleadas have sleeping quarters in an area separate from the family area, and this arrangement was evident in all the houses in which I conducted fieldwork. These generally accepted expectations 
on the part of the señoras provide clear examples of how social distance is maintained between employers and domestic workers.

The señoras acknowledged having had both good and bad experiences with the women working in their houses. They did not understand the reasons for the bad experiences as they all believed their treatment of empleadas was good. "Las trato bien" (I treat them well) was the standard reply. When I asked them what they meant by "good treatment," they answered that they often give the empleadas permiso (permission to leave for personal errands) if asked and allowed them to watch TV after the work day was over; that the empleadas also ate the same food as the family and were provided hot water, toilet paper, soap, toothpaste and sometimes other toiletries in their bathrooms. Señoras also claimed they paid empleadas on time, and twice a year, in July and December, gave them a gratificacion, which is an additional half month's salary for Independence Day (July 28) and Christmas.

Señora Veronica noted that she also pays social security for her empleadas (the cost is 47 soles per month or US\$21 in August 1995) and paid for their medicines if needed. Señora Lorena's empleadas, on the other hand, do not have social security, but she indicated she would be more than happy to pay for it if only her empleadas would go to complete the tramite (paperwork) required. Bunster and Chaney, however, assert that the señora must go with the empleada to arrange social security enrollment, but that empleadas prefer not to enroll in social security "because one-half the payment would be deducted from their . . salaries" (1985:29).

In general, the señoras agreed that they considered the empleadas part of the family. When I asked them to clarify what they meant, Señora Veronica told me that she bought things for the empleada and her children; gave her clothes that were out of style or no longer fit her or her children; and, if she had extra frozen food, she asked her empleada to take it with her when she left on her day of salida. Señora Paula felt that she treated her empleadas with respect and never humilliated them, and to help them out, she also gave them things she no longer used. Señora Andrea mentioned that she frequently goes to restaurants during weekends with her 
husband and children accompanied by the empleada, who will sit with the children and be allowed to choose and order her own meal.

The señoras, however, felt that their empleadas sometimes took advantage of them. One of the things seen as abuse is the fact that empleadas eat a lot of food, and sometimes steal things that are of little value. For example, during the summer they would steal winter clothes; and during the winter, summer clothes. Other things that my informants claimed were stolen are food and children's toys. The señoras give little thought to these inconsequential thefts as they need to have empleadas in the house. The alternative meant searching for a new empleada or doing everything themselves.

\section{SECONDARY PARTICIPANTS}

\section{The Children of the Household}

A different kind of relationship is established between the empleadas and the children living in the household. It is not unusual for children raised in a household with empleadas to develop strong ties with their caretakers, as they spend many hours together. The prevailing isolation endured by empleadas in their workplaces is in many ways counterbalanced by the development of very close relationships with the younger children of the household. Without exception, the empleadas I interviewed said they felt very comfortable with the children of the house and had become very attached to them. As the children of the household spent more time with them than with their mothers, this established the basis for very trusting and dependent relationships between the empleada and the household's children. Often, the children trusted and confided in their niñeras, amas, or other live-in workers rather than with their mothers.

Pepita, an ama, spends most of her time with the children of the household. She sleeps in the children's room, wakes them up every morning, feeds them, dresses them, and walks the oldest one to school. In the afternoon, after lunch, she washes the children's clothes by hand and, after their nap, she plays with them. At night time, she gives them dinner and bathes them 
before putting both children to bed by 7:30 p.m. If the children are sick, she will wake-up at night to give them medicine or to check periodically their status. One afternoon after being summoned by Señora Maria Eugenia to take the children back to the playroom, Pepita told Señora Maria Eugenia in front of me "usted se aburre de sus hijos" (you seemed bored by your children). Pepita told me that her employers rarely spent more than an hour at a time with their children. Despite the fact that Pepita has minimal time for herself, she believes the best part of her job is the relationship with the children under her care to whom she has become very attached. In my interviews with Pepita, she assured me that the señora had the right to ask her to spend time with her children because she was receiving a salary for it.

If there is nothing planned in the afternoon, amas may take the children to the park. In the park, the ama discovers a unique opportunity to make friends with other empleadas on similar outings. The children will play together while the workers socialize. This is one of the rare occasions upon which empleadas can socialize with women of their same social class away from the watchful eye of their employers. The only other occasion when this occurs is when they take the children of the household to birthday parties. However, most empleadas did not like attending these events. At the party, the ama has to make sure that the child (or children) under her care are well behaved and do not dirty their clothes (as appearances are very important in upper-middle class surroundings), and that the children interact in a socially correct and proper manner with any adults attending the party. If a child is shy or does not know anybody at the party, the ama tries to persuade him or her to play with other children. In these instances, the ama provides a sense of security for the children in an unfamiliar environment.

Empleadas admitted to being puzzled by the fact that their employers did not take care of their children's need or provide comfort to them if they were upset or sick. In this regard, the empleadas claimed that they were expected to fulfill the role of mother. Furthermore, the empleadas I interviewed stated that they are expected to be patient and loving with the señoras' children, even though they were aware of the señoras' lack of patience and subsequent inability to spend an entire day with their own children. The empleadas pointed out that señoras 
displayed fleeting affection for their children by kissing them, telling them how good they were and how pretty they looked, and then immediately sending them away. Perhaps Alfredo Bryce Echenique (1984), in Un Mundo para Julius, best describes the relationship established between children and domestic workers. He narrates the story of Julius, an upper class boy growing up in San Isidro, and his relationship with domestic workers employed by his mother. Julius became very attached to Vilma, his ama, and Nilda, the cook. The servants of the household adored Julius, but were critical of Julius' mother. Although Bryce Echenique's work is fictional, the relationships described throughout his book reflect the attitudes and situations recounted by my informants.

The señoras, however, do not necessarily see any conflict in their self-described roles as mothers, even though they do not perform any tangible childcare activities. According to their beliefs, a mother is indispensable and should be available for her children at all times, but not necessarily to cook, clean, or help them dress. Occasionally señoras do find the "perfect" empleada, somebody who meets their high standards. One of my informants claimed:

Doris was my oldest daughter's ninera. She did everything in the house. She cooked, sewed, and knew how to do everything when the other empleadas were not around. She was different from the other empleadas. She 'educated' my daughter, she had a routine with her, toilet trained her before she was 18 months, taught her how to eat with a fork, taught her games, she had her dressed nicely at all times, and dedicated many hours to play games with her (Field notes, 1995).

My informant's expectation of having her child "educated" by her niñera is interesting because empleadas are usually lower class and uneducated. Despite this fact, señoras demand that these women socially orient their upper-middle class children in an environment that is completely alien to anything that empleadas have experienced prior to their migration to the city. In fact in this context the señoras did not acknowledge or question the differences in cultural background between themselves and their empleadas; they just expected their workers to enforce rules of upper class behavior and teach their children to play and paint.

Señoras voiced disapproval of any empleada requiring constant supervision or needing to be reminded of her duties, as they found this task extremely tiresome. Common complaints 
regarding childcare duties included the need to remind or question empleadas as to whether the children of the house had been fed their milk, eaten lunch or dinner, or had taken their baths. Other complaints stemmed from the empleada's inadequacy in keeping their children's room in order. If an empleada challenges the señora's authority or does not follow orders an immediate conflict is likely to arise. If there is no resolution to the problem, the empleada will be asked to leave immediately. Children are rarely, if ever, told when an empleada is leaving the household.

The señoras did acknowledge that their children get emotionally upset after their niñeras, amas, or other live-in workers leave the household. It is not unusual for small children to request their mothers to bring their niñeras or amas back following a dismissal. Some señoras were puzzled by the fact that their children missed their nineras or amas "as if their mother had left." One of the señoras offered her opinion on this matter:

Niñeras and amas can do much harm to children because children become emotionally dependent upon them, and then the nineras and amas leave, leaving behind a hole difficult to assimilate for most children (Field notes, 1995).

In this particular case, the señora's child had become extremely attached to her niñera and missed her for months after she left, and even today, many years later, the child still remembers her niñera. The señoras I interviewed agreed that empleadas are to be blamed for creating insecurities in their children. As Susan Cheever pointed out in an article in The New Yorker, employers "get very angry when a nanny leaves . . .(they) seem to feel abandoned, even when the nannies have been fired." In fact, one of my informants stated that after dismissing a particular ama, she locked herself in her bathroom and cried for an entire hour, as she was unable to face her child's devastation at the loss of her ama.

\section{The Señores of the House}

A man is never involved in household organization, childcare arrangements, or day-today domestic problems, although within his household a man has the power to intervene and challenge the orders of his wife (Gill, 1994). In most cases, the husband will back his wife in her 
household decisions. If his wife has any serious complaints regarding empleadas, the husband may intervene and will try to negotiate a solution. Serious issues may include empleadas asking for raises, permission to take holidays during a time when there maybe parties scheduled at the household, and specifically whenever the empleada questions the role of his wife as mother. As opposed to his wife, he does not have any emotional relationship with the domestic worker and it is easy for him to address the worker in an authoritarian manner. He may reprimand the worker and ask her to comply or abide by his wife's order, if this does not happen, the husband explains to the worker that she will immediately be dismissed and have to leave the household.

During interviews, empleadas stated that they respect men employers more than they respect women employers. Domestic workers believe that upper-middle class men are very busy, always working to provide for the family and they will go to great lengths to not upset them. I noticed that empleadas seemed to be intimidated in the presence of male employers and would only address them when passing telephone messages or serving them meals. If, for any reason, the husband addressed the empleada directly she appeared to be afraid. However, his wife was always present to instruct the worker in how or what to serve her husband. It is unlikely that a man will eat breakfast, lunch or dinner at home without his wife being present.

Norma Fuller (1997) argues that Peruvian middle class men are socialized in a "cultura masculina" (masculine culture) that allows them occasional ways to transcend social hierarchy. She points out that the game of soccer unifies men of all ages and statuses into precise categories that will identify them as belonging to specific clubs (Alianza Lima, Universitario de Deportes, Sport Boys, etc.) which is conducive to and allows them to transcend class, race, and ethnicity, but never gender. Therefore, this category which she calls "los hombres" (the men), creates a public neutral space in which the street is seen as a place for men (1997:118). She further notes that women represent order and hierarchy and are never trained in a language that promotes interclass familiarity (1997:118). Therefore, men can be profoundly hierarchical in their households and work, but are allowed to share certain masculine activities outside both their households and their work places that break class distinctions. 
With regard to marriage, Fuller argues that socio/racial endogamy in Peru is very strict within the middle classes (1997:158). She further states that in those cases where a man might consider marriage outside the stipulated social and class boundaries there is likely to be considerable comment within the family concerning the problematic consequences that such a union will cause for the entire family. The extent of familial interference will be limited to negative commentary (1997:158).

Fuller contends that the division of labor within middle class Peruvian households is still seen by the males as corresponding to the wife. Nevertheless, in the interviews she conducted with forty middle class Peruvian men, they exhibited a need to justify their own positions in this respect. Some expressed guilt, while others indicated that this division of labor within the household is not a problem because it is the empleada who does the chores. Fuller argues that only a minority of males said they attempt to participate in an active manner in the house (1997:160). In conversations I had while conducting fieldwork, the señores noted that they expected to be served because they worked hard outside the household and were good providers. Both the señora and empleada did agree that the señor of the house had to be served (Field notes, 1997).

Fuller also notes, however, that men expressed the belief that their wives' first preocupation should be with their children, and that correspondingly women should stay home with their children, who need the presence of their mother in the home (1997:161). These men perceived their role as that of provider and mentor to their children. Nevertheless, Fuller argues that the relationship of a man with his children will be gender biased. As she notes, the father sees a boy as the perpetuation of his family name, while his relationship with a daughter will be more affective (1997:167).

Fuller concludes that the basic premises of masculine domination in Peru have not changed. Moreover, she states that males as a group continue to maintain a monopoly on the economic and political life of the country as well as being the main authority within the household $(1997: 60)$. 


\section{CONFLICT AND MUTUAL DISTRUST}

\section{Household Privacy}

The concept of "privacy" as understood in the United States is alien to my señora informants as they have had "outsiders" living within their households all of their lives. One of my informants has to have an empleada from Monday until Sunday which prevents her from spending any private time with her husband and children. The empleadas' quarters are separated from the family's quarters by the kitchen door; still, the empleadas spend much of their time with the children as they can't be left unattended. Because of this, the empleadas will overhear arguments, discussions, and will be aware of every trouble and tribulation the family is experiencing. My señora informants acknowledged that their empleadas know when something was not going well in the household. However, the señoras insisted they preserved their intimacy by not telling their empleadas about their worries and troubles of the moment. Another señora informant told me she is very much aware of the fact that her empleadas know "when something is not quite right." She lives in a home whose area is 800 square meters, and has two floors. Not counting the kitchen area and empleadas' quarters, the house is comprised of three formal living rooms, one formal dining room, two family rooms, four bedrooms, an outside garden with a pool and bar, a gym, and separate area, isolated from the house, on the second floor, where she and her husband have a family room, bedroom, closets, bathrooms, and a terrace with chairs and a dining room overlooking a park in San Isidro.

The size and layout of this house seemed to provide a certain degree of privacy, and I would have assumed that the family was able to "preserve some privacy." However, the señora confided that from time to time the empleadas will plead with her, "señora, stop arguing with your husband for the sake of the children." Another señora told me she did not discuss her personal problems with her empleadas, and prefers to keep them at arm's length to avoid problems. She did acknowledge that she will tell her empleadas false stories about her economic worries and 
problems, and even though they are not true, she feels that in this way she can avoid abuses and requests for raises in their salaries so often.

In my interviews with empleada informants, it became extremely obvious that they were not only reluctant to discuss their lives with their employers, but that there existed no manner of communication that would allow an empleada to talk openly and freely with the señora. The only times when this communication gap was breached appeared to be in the event the empleada required financial assistance. My informants confessed that they feel there is "no confianza" (no trust) between them and their employers. Pepita told me she had no trust in Señora Maria Eugenia, even though she believes "Señora Maria Eugenia understands her" (she has received financial help from the señora). Dolores also told me that she only trusts Señora Maria Eugenia "un poco" (a little). She explained that she has requested economic help in times of need from the señora, however she stated she has never told her of her life and problems. She believed Señora Maria Eugenia had enough problems to be bothering her with her own.

\section{The Señoras and the Empleadas}

Conflict according to both señoras and empleadas are not fights. They are just disagreements. Señora Lorena and Rosa, the cook, had a disagreement concerning Rosa's salary that ended in Rosa getting fired. Señora Lorena fired her thinking that it was going to be easy to find another cook, while Rosa left thinking Señora Lorena was not going to find a replacement. Señora Lorena, however, found a very good cook and forgot Rosa completely. According to Señora Lorena's version, Rosa kept calling her house every week to ask about her daughters whom she missed very much. After many calls, Señora Lorena became aware from the other empleadas that Rosa had been unable to find another job and was desperate for work. Señora Lorena felt a little sad but did not want Rosa to return to her household. As Rosa was an empleada de confianza (empleada of trust), Señora Lorena recommended Rosa to her sister-inlaw, who was looking to hire a cook. In the meantime, Rosa continued to miss the daughters of 
Señora Lorena. Finally, Señora Lorena decided to send her youngest daughter to Lurin (the marginal town in which Rosa lived) to visit Rosa with Teresa, another empleada employed in her house and niece of Rosa). The four year old girl and Teresa, her ama, took a micro (a small, usually very crowded bus) and Señora Lorena's husband gave them a cellular phone just in case. After the visit, Teresa and the little girl returned home by taxi.

Eventually, Señora Lorena had a big fight with the new cook and decided to fire her. Her husband, tired of hearing about the domestic problems, suggested that his wife re-hire Rosa because he felt that "Rosa was the perfect empleada." He felt that Rosa had served him correctly and reminded his wife that they did not have to repeat requests to Rosa and then emphasized the love Rosa felt for their daughters. Señora Lorena called her sister-in-law to tell her she wanted Rosa back in her house. As Rosa had not yet become used to her household and obviously missed Señora Lorena's children too much, the sister-in-law readily agreed. Señora Lorena explained to me that Rosa was re-hired because she was una empleada de primera (first-rate maid) who allowed her to run her household properly. Señora Lorena said she forgave Rosa because she could do a little bit of everything.

Rosa on the other hand, had a different version. Rosa did not refer to any fights between herself and Señora Lorena. According to Rosa she returned to Señora Lorena's household for various reasons. First, she did not like the area in which Señora Lorena's sister-inlaw lived; and second, she missed the children of the household. The youngest daughter had become very attached to her, and she proudly told me that the señores had allowed their three year old daughter, or "the gringuita" as she calls her to come and visit her in Lurin. According to Rosa that meant that the señores trusted her because they knew she was going to treat their daughter well. Apparently, as soon as the child arrived to her house in Lurin she had asked Rosa to cook and feed her, after which the little girl asked Rosa to show her the pigs being raised on Rosa's land. Rosa's mother, an Andean migrant from Apurimac, was very surprised to find out "the gringuita had never seen pigs," while the little girl on the other hand, had been surprised when she saw Rosa's father weaving straw baskets to sell in the market. Rosa explained to me 
that the reason why she returned was because she always "kept her place" with the señores and had always been good to them. She added that whenever she left the household in which she worked she had always left on good terms. Rosa also told me that she was a very faithful person.

Upon Rosa's return, Señora Lorena and Rosa agreed to split the difference of Rosa's demand for a salary increase and the problem seemed to have been resolved amicably. However, I was able to observe that Señora Lorena and Rosa avoided talking to each other. Señora Lorena told me she does not trust Rosa anymore and prefers to keep her at a distance. Similarly, Rosa told me she knew her place and insisted that because she knew her place there had been no conflict between herself and the señora. Rosa chose to focus her explanation on the fact that Señora Lorena's sister-in-law lived very far away, in Las Casuarinas. It should be noted that as a matter of fact Las Casuarinas is geographically a lot closer to Lurin (where her home is located) than San Isidro. Rosa then quickly shifted the subject of conversation to the family she had worked for before coming to work in San Isidro for Señora Lorena. Rosa seemed very judgmental of the señora she had worked for in the past and had very harsh words for her; however, when she spoke of the señora's husband, she expressed admiration and gratitude. Rosa acknowledged that she had hardly seen the señor, but she felt he was a hard-working man as opposed to his spoiled wife, who did nothing around the house. Overall, Rosa seemed cautious with me and did not want to talk about Señora Lorena. I realized that the mutual distrust between them had extended to me because Rosa saw me as a señora rather than as an impartial observer and outsider. Neither Señora Lorena nor Rosa trusted each other completely and our conversation was ended quickly when Señora Lorena sent for Rosa to bring us coffee. Another example of conflict in the household was the disagreement between Señora Pilar and Cristina. They both had a very strong argument that was diffused by the quick intervention of Señora Pilar's husband. Señora Pilar, who was pregnant, had started to argue with Cristina over Cristina's apparent bad mood. The señora was extremely upset by Cristina's 
temper and told her to leave if she was not happy working in her household. "You have the doors open and can leave whenever you please," said Señora Pilar to Cristina. Interestingly, according to Señora Pilar, this comment indicated that she had fired Cristina, while her husband, on the other hand, told me that it didn't mean anything. At the time of the argument, Señora Pilar's husband was present and he had tried to soften things out between his wife and Cristina and asked Cristina to understand that his wife was pregnant. To avoid further arguing he decided to take his wife out for a drink, and I saw them both immediately after the argument had taken place. Señora Pilar seemed to be extremely agitated and her husband was trying to calm her down by reminding her not to give too much importance to Cristina's moods. He also told his wife that in order to avoid further problems with Cristina she should never argue with her again, as "la clave es ordenar, no discutir" (the key is to order her, not argue with her). Señora Pilar seemed to be very upset with her husband's comments which she said were condescending and unrealistic. She claimed to be sick and tired of Cristina's argumentative nature which he rarely saw, and in addition, she had to deal with Cristina's bad moods on a daily basis. This issue was discussed in my presence for over one hour. In the end, the señora did not fire Cristina, but rather Cristina decided to ask permission to go back to visit her Andean hometown in Arequipa. Cristina was gone for one month, during which time Señora Pilar was desperate without her. By the time Cristina finally returned from Arequipa, loaded with presents for the señora, the señor, and the baby, everybody was happy to see her back. The señor and señora decided to go away for a few days to relax leaving behind their son with Cristina.

When I asked her about this episode, Cristina, who has been my informant for the past two years, also understated the incident and only mentioned that Señora Pilar was not having a very good pregnancy and seemed to be very tired. Afterwards, I noticed that both Señora Pilar and Cristina seemed to be uncomfortable in each other's presence and avoided looking or talking to each other.

The señoras I interviewed all had similar stories, which they told not only during interviews, but also during parties and at other social gatherings. One woman told me that even 
now, two years after firing an empleada that worked in her household for ten years, she does not understand how she was able to deal with her for so long without confronting her for not performing her chores. This señora stated that the empleada had completely dominated her with her passivity." Another woman was in agreement with that remark and added that her mother had had the same problem with a woman employed in her household for over thirty years. She had observed that the relationship between her mother and the empleada seemed to be quite different from that of the husband and children of the household with whom the empleada had never had any kind of conflict during the past thirty years of employment. She claimed that for as long as she could remember, her mother had had strong disagreements with the empleada and the last one they had a few weeks ago had ended with her mother in the hospital. Still, the empleada had not been fired because her mother felt that she could not handle the household without the trusted empleada's help.

During the interviews, I became aware that the various accounts given to me by the señoras all had a common theme, which was the relative distrust they felt for the women employed in their households. In similar fashion, the empleadas' accounts also had the distrust theme, although it was addressed only in reference to prior employment and not their current situations. The relationship and interaction between the señora and the empleada is extremely complex and cannot be fully explained in terms of class conflict. The mutual distrust felt by señoras and empleadas does not seem to extend to the other members of the household and even though the señoras did not seem to have a problem establishing physical distance through the clearly delineated social spaces, they did seem to have difficulty in establishing emotional distance from the women employed in their houses. The señoras spent an enormous amount of time discussing their constant problems and conflicts with empleadas. Wherever I went, the topic was brought up and discussed at length and solutions were offered by empathetic señoras. Without exception, all the señoras appeared to be completely dependent on their empleadas and felt threatened to the point of desperation if conflict arose. 
The ambiguity between establishing physical and emotional distance did not appear to be shared by the señoras who worked outside their homes. In my interviews with them, they emphasized that they did not view or consider empleadas working in their household as "part of their family." Working señoras noted that the women employed in their households were doing a job and getting paid for it. They added that in their places of employment or offices each member had to perform a job and as a result received a salary. They saw no difference between the people employed in their offices and the women employed in their households. Most working women interviewed were professionals and held very high positions as lawyers or managers. In their responses, it also became clear that they had no problem establishing physical or emotional distance with the empleadas in total contrast with the nonworking señoras. At the same time, working señoras seemed to spend less time talking about their empleadas and if any problem or conflict arose, they immediately confronted the issue and gave a warning to the empleada. The working women interviewed were more prone to hire empleadas through agencies. As one of my informants suggested, although expensive, empleadas provided by Nana Servis come with recommendations and were given a thorough medical check-up before the agency sent them to their new place of work. This same informant told me that she would prefer not to deal with empleadas, but that she needed them because she works and has small children. However, after saying this, she paused and thought about it for a while before telling me that, even if she didn't work, she would still hire empleadas because without them "it would be impossible to have a life." 


\section{CHAPTER IV: CONCLUSION}

The issue of basic rights for domestic workers addressed in this thesis has recently become the subject of heated public debate in Lima (Muñoz Nájar, 1996). In a telling development, new legislation passed by the Peruvian Congress to regulate salaries and working conditions of empleadas was vetoed by the Peruvian President, Alberto Fujimori, as a result of the outburst of public opinion against such change. Labor advisors in Peru argued that the implementation of the law would drive inflation and raise unemployment, while a spokesperson for the Center of Training for Household Workers in Lima described the current situation as "feudalistic."

The empleadas who migrated from egalitarian Andean villages experienced a significant culture shock when moving from the simple communal lifestyle of their Andean origins to the faster paced and obviously hierarchical society of Lima, where they are considered less than equal. Empleadas want to be accepted and want to achieve the invisibility associated with belonging, and as such, continually strive to adapt socially to their new environment from the first day of their arrival in the city. As my paper has shown, the empleadas in this study have each adapted to the Lima environment in different ways. If given the opportunity to relive their lives, however, some of them indicated they would have stayed living the simple but happier life in their home villages, while others would not consider leaving the life they have found in the city.

Each of my empleada informants is caught in a vicious cycle where their newly discovered needs can only be maintained by greater economic means. While they do not like working as empleadas, and they do not want their children to follow in their footsteps, their lack of prospects for gainful employment provide few solutions to their economic problems. They can only raise their level of education to allow them to assume a different type of work, or marry someone who can help them break free of the yoke of domestic servitude.

My research suggests that the señoras' attitudes result from their distinctive cultural and social environment. From birth, these women are presented with a social model of "them" and 
"us" which becomes so strongly embedded in their belief system that as adults they easily recognize "them" and "us" without the need for explicit labeling. The distinct social differences between themselves and anyone of a lower class, including their domestic workers, makes this differentiation second nature. The señoras are able to identify the cultural differences, and as a result, almost disregard the fact that empleadas are women like them who, due to poverty and a lack of education, can only obtain employment as domestic workers. The señoras view all disharmony in the household as the result of empleadas' non-compliance with their orders, and thus, in the event of a conflict, the empleada is always at fault. Social stratification in Peru has allowed upper-middle class women to continue to perpetuate many myths and stereotypes about empleadas, however, the señoras interviewed indicated that they would be unable to maintain their socially expected lifestyles without the help of empleadas. Furthermore, it became apparent during my research that the señoras had refined their management of domestic service to such an extent that for them it had become an art-form of which they were justifiably proud.

As a result of my research, I have come to understand the extent of the lack of communication between the empleadas and their employers. On the one hand, the empleadas are unable to verbalize their situation because of a lack of education and an incomplete understanding of the extent of their basic rights. On the other hand, the señoras have generations of hierarchical examples showing them they have every right to expect unquestioned subservience from their lower class employees.

The empleadas were very much aware of class differences at all times; and while their employers never referred to these differences, the empleadas always "knew their place." Empleadas dared not use the same furniture as their employers, did not sit at the same table, share the same food, or eat at the same time as their employers. Empleadas had their sleeping quarters invariably in a separate area near the kitchen and laundry areas, they had to wear uniforms, and had to address their employers respectfully as "señor" and "señora," while they in turn were addressed by their first names. The social distance resulting from these inbuilt, required, and accepted forms of address and response create an insurmountable barrier from 
which the señora and the empleada both contribute towards maintaining social distance between themselves.

My study shows that the delineation of space within the household is clearly and indisputably divided between those areas of limited access and areas of free access to the empleada. The boundary line between these two physical spaces is the kitchen door which acts as a visible reminder of the unspoken differences between the empleada and the other members of the household who have no such constraints.

The American notion of privacy is non-existent in a Peruvian household. The empleadas in my study are aware of every nuance and conflict experienced by the members of the family but remained uninvolved as they are not asked to comment or give an opinion in these circumstances. At the same time, empleadas are also very much aware of their place in their household and the relative unimportance of their opinions to their employers. While empleadas may discuss household issues among themselves, they also keep their own lives very private unless they need urgent economic assistance, in which case they will involve the señora in the hope that they will obtain the necessary help needed to resolve their problems. The empleada, however, only becomes visible in the event of conflict between herself and the señora in which case the true power associated with her knowledge of intimate family details becomes apparent, and rarely would such conflict result in the loss of employment. As Margo Smith suggests "within the context of the family and household, the servant is its most visible invisible member" (1971:108).

Goffman's theory of "team work" is easily adaptable to the convoluted relationship between the señora and the empleada which is based on both: their physical closeness as a team for the completion of household tasks and the presentation of the household to outsiders; and their mutual distrust of each other as a result of the social implications of their roles. Peruvian society is elitist and while the relationship in the confines of the household maybe mutually trusting, this closeness is thwarted by the involvement of persons external to the immediate family to whom their relationship must be maintained as one of social distance. 
Señoras are concerned with maintaining appearances and this social requirement of not showing public association outside immediate social boundaries is so strong that any opportunity for expanding the relationship between themselves and domestic servants is impossible.

In this respect, my position as both a señora and a researcher inhibited my ability to obtain complete trust and openness from the empleadas. As noted by Smith, even though she was not Peruvian, her obvious social status characterized her as a señora. The señoras perceived her as a social equal while the empleadas perceived her as señora. Although more than twenty five years have passed since Smith conducted fieldwork in Lima, there seems to be a definite continuity with my work which suggests a stability for the institution of domestic service. Domestic service is critically important in the organization of family and household relations in the Peruvian household, and affords the señoras a degree of freedom rarely experienced in other societies. I have provided a first order interpretation of the characteristics of the relationship while providing data that can be used by other analysts to: check against their accounts of domestic service in other societies; to compare with earlier and later accounts of it in Peruvian society; and to be used to examine other topics and issues that cross-cut with the organization of upper class households, internal migration in Peru, and racial, ethnic, and gender aspects of stratification. 


\section{References Cited}

Abu-Lughod, Lila

1991 "Writing Against Culture". In Recapturing Anthropology: Working in the Present.

Richard G. Fox, ed. Pp. 136-162. Santa Fe: School of American Research Press.

Adrianzén, Alberto

1990 "Estado y sociedad: señores, masas y ciudadanos." In Estado y sociedad: relaciones peligrosas. Pp. 13-42. Lima: DESCO.

Apoyo - Opinión y Mercado S.A.

1996 Niveles Socioeconómicos Gran Lima. Area: Estudios Cuantitativos Estadística. Lima.

Appiah, K. Anthony and Amy Gutman

1996 Color Conscious: The Political Morality of Race. New Jersey: Princeton University Press.

Barnechea, Alfredo

1995 La República Embrujada: Un caso en la pobreza de las naciones. Lima: Aguilar Nuevo Siglo.

Bee, Elena

1996 "The Other Side of the Kitchen Door: Upper-middle class Women in Lima, Peru and their Relationship with Household Workers." Presented in session "Women's Bodies: Social Hierarchy, Violence, and Ethnicity in Latin America" at the annual meetings of the American Anthropological Association, November 24, 1996, San Francisco.

1997 "The Bottomless Cup of Coffee: Interviews with Upper-Middle Class Women in Lima, Peru." Presented in session "Taking Testimony: Telling Lives" at the 44th annual conference of SECOLAS. February 28, 1997, San José, Costa Rica.

1997 "Dishes, Diapers, and Disposable Friends: Domestic Service in Lima, Peru." Presented in session "Showcase of Student Research on Gender" at the 15th Annual Women's History Month Conference. April 5, 1997, Miami, Florida.

Bordieu, Pierre

1984 Distinction: A Social Critique of the Judgement of Taste. Richard Nice, trans. Cambridge: Cambridge University Press.

Bourque, Susan C. and Kay Barbara Warren

1981 Women of the Andes: Patriarchy and Social Change in Two Peruvian Towns. Ann Arbor: The University of Michigan Press.

Bourricaud, François

1975 "Indian, Mestizo and Cholo as Symbols in the Peruvian System of Stratification." Barbara Bray, trans. In Ethnicity: Theory and Experience. Nathan Glazer and Daniel P. Moynihan, eds. Pp. 350-387. Cambridge: Harvard University Press.

Bunster, Ximena and Elsa Chaney

1985 Sellers and Servants: Working Women in Lima, Peru. New York: Praeger Publishers.

Bryce Echenique, Alfredo

1984 Un Mundo para Julius. Bogota: Editorial La Oveja Negra Ltda. 
Burkett, Elinor C.

1975 "Early Colonial Peru: The Urban Female Experience.” Ph.D. diss., University of Pittsburgh.

1978 "Indian Women and White Society: The Case of 16th Century Peru." In Latin American Women: Historical Perspectives. Asunción Lavrin, ed. Pp. 101-128. Westport: Greenwood Press.

Callirgos, Juan Carlos

1993 El racismo: La cuestión del otro (y de uno). Lima: DESCO.

Chaney, Elsa M. and Mary Garcia Castro, eds.

1989 Muchachas No More: Household Workers in Latin America and the Caribbean. Philadelphia: Temple University Press.

Cheever, Susan

1995 (March 6) "Annals of Domestic Life: The Nanny Track." The New Yorker. Pp. 84-95.

Colen, Shellee

1989 "'Just a Little Respect': West Indian Domestic Workers in New York City." In Muchachas No More: Household Workers in Latin America and the Caribbean. Elsa M. Chaney and Mary Garcia Castro, eds. Pp. 171-194. Philadelphia: Temple University Press.

Compendio Estadístico 1991-1992. Lima - Callao

1992 Dirección Nacional de Estadísticas Regionales y Locales.

Cook, Noble David

1968 Padrón de los indios de Lima en 1613. Lima: Seminario de Historia Rural Andina, Universidad Mayor de San Marcos.

1981 Demographic Collapse: Indian Peru, 1520-1620. Cambridge: Cambridge University Press.

De Soto, Hernando

1986 El Otro Sendero: La Revolución Informal. Lima: Editorial El Barranco.

Fuenzalida Vollmar, Fernando and Enrique Mayer

1974 El Peru de las Tres Razas. New York: Instituto de las Naciones Unidas para Formación Profesional e Investigaciones.

Fuller, Norma

1997 Identidades Masculinas: Varones de Clase Media en el Perú. Lima: Pontificia Universidad Católica del Perú.

Garcia Castro, Mary

1989 "What is Bought and Sold in Domestic Service? The Case of Bogota: A Critical Review." In Muchachas No More: Household Workers in Latin America and the Caribbean. Elsa M. Chaney and Mary Garcia Castro, eds. Pp. 105-126. Philadelphia: Temple University Press.

Gilbert, Dennis

1981 "Cognatic descent groups in upper-class Lima (Peru)." American Ethnologist, 8:4, November 1981. Pp. 739-757. 
Gill, Lesley

1994 Precarious Dependencies: Gender, Class, and Domestic Service in Bolivia. New York: Columbia University Press.

Goffman, Erving

1959 The Presentation of the Self in Everyday Life. New York: Anchor Books.

Hall, Edward T.

1959 The Silent Language. New York: Doubleday \& Company, Inc.

1966 The Hidden Dimension. New York: Doubleday \& Company, Inc..

Kuznesof, Elizabeth

1989 "A History of Domestic Service in Spanish America, 1492-1980." In Muchachas No

More: Household Workers in Latin America and the Caribbean. Elsa M. Chaney and Mary Garcia Castro, eds. Pp. 17-35. Philadelphia: Temple University Press.

Lockhart, James

1994 Spanish Peru 1532-1560: A Social History. Second Edition. Madison: The University of Wisconsin Press.

Loza, Martha, Paulina Luza, Rosa Mendoza, and Flor Valverde 1990 Asi, Ando, Ando Como Empleada. Lima: IPEC.

Matos Mar, José

1988 Desborde Popular and Criss del Estado: El nuevo rostro del Peru en la década de 1980. Lima: CONCYTEC.

Muñoz Nájar, Teresina

1996 "Buenas Muchachas." In Caretas, No. 1434, October 3, 1996.

Murphy, Robert

1971 The Dialectics of Social Life: Alarms and Excursions in Anthropological Theory. New York: Basic Books, Inc. Publishers.

Nash, June and Helen Icken Safa

1980 Sex and Class in Latin America: Women's Perspectives on Politics, Economics and the Family in the Third World. New York: J.F. Bergin Publishers, Inc.

Oboler, Suzanne

1995 Ethnic Labels, Latino Lives: Identity and the Politics of $(R e)$ Presentation in the United States. Minneapolis: University of Minnesota Press.

Portocarrero, Gonzalo

1990 "El silencio, la queja y la acción: Respuestas al sufrimiento en la cultura peruana." In Tiempos de ira y amor. Pp. 223-243. Lima: DESCO.

Powdermaker, Hortense

1966 Stranger and Friend: The Way of an Anthropologist. New York: W.W. Norton \& Company Inc.

Rollins, Judith

1985 Between Women: Domestics and their Employers. Philadelphia: Temple University Press. 
Romero, Mary

1992 Maid in the U.S.A. New York: Routledge.

Sarfatti Larson, Magali and Arlene Eisen Bergman

1969 Social Stratification in Peru. Politics of Modernization Series, No. 5. Institute of International Studies. University of California, Berkeley.

Smith, Margo Lane

1971 "Institutionalized Servitude: The Female Domestic Servant in Lima, Peru." Ph.D. diss., Indiana University: Bloomington.

Spalding, Karen

1970 "Social Climbers: Changing Patterns of Mobility among the Indians of Colonial Peru." Hispanic American Historical Review, 50.

Spradley, James P. and Brenda J. Mann

1975 The Cocktail Waitress: Woman's Work in a Man's World. New York: John Wiley \& Sons, Inc.

Spradley, James P. and David W. McCurdy

1972 The Cultural Experience: Ethnography in Complex Society. Prospect Heights:

Waveland Press.

van den Berghe, Pierre L. and George P. Primov

1977 Inequality in the Peruvian Andes: Class and Ethnicity in Cuzco. Columbia: University of Missouri Press.

Vergara Ormeño, Teresa

1997 "Migración y Trabajo Femenino a Principios del Siglo XVII: El Caso de las Indias de Lima." Histórica, Vol. XXI, no. 1. July 1997, Pp. 135-157. 